\title{
DIRECTORS' REMUNERATION: A COMPARISON OF ITALIAN AND UK NON-FINANCIAL LISTED FIRMS' DISCLOSURE
}

\begin{abstract}
:
Directors' remuneration is a key issue for both academics and policymakers. It has caused enormous controversy in recent years. This study uses a comprehensive index to analyse the disclosure of directors' remuneration in Italian and UK listed firms. It finds that the level of voluntary disclosure is significantly associated with firm-specific incentives, such as the demand for information from investors and the need for legitimacy. It finds that the level of voluntary disclosure is significantly higher in the UK than in Italy and that firm-specific incentives to disclose voluntary information differ according to the institutional setting in which a firm operates. In the UK, firm-specific incentives mostly come from the demand for information, estimated with the level of ownership diffusion, and the need for legitimacy generated by poor market performance and shareholders' dissent. In Italy, firm-specific incentives seem to be represented by the need for legitimacy generated by media coverage. This study also provides evidence that, in both countries, the information disclosed in corporate documents does not allow readers to obtain a comprehensive picture of directors' remuneration. Bonuses are poorly disclosed even though they are a key element of directors' remuneration. This finding is clearly important for policymakers at European and national level.
\end{abstract}

Keywords: agency theory, directors' remuneration, disclosure, legitimacy theory. 


\section{Introduction}

Directors' remuneration aims to align the interests of directors with those of shareholders, thereby reducing agency problems (Jensen \& Meckling, 11976). However, directors' remuneration, of itself, could give rise to agency problems (Bebchuk et al., 2002). This is one of the key areas where directors may have a conflict of interest and where due account should be taken of the interests of shareholders (EU Commission, 2004). Controversy surrounding directors' remuneration reflects the perception that payments have been excessive and that the lack of timely and adequate disclosure has resulted in increased information asymmetry and rent-extraction (Bebchuk et al., 2002, Jensen et al., 2004). The demand for public disclosure arises from information asymmetry and agency conflicts between directors and outside investors (Healy \& Palepu, 2001). Disclosure on directors' remuneration would help to resolve such problems. It can reduce information asymmetry on complex remuneration arrangements that can be an important mechanism to transfer wealth from shareholders to directors (Bebchuk et al., 2002; Laksmana, 2008; Nelson et al., 2010). Moreover, directors' remuneration has been blamed for playing a central role in many international corporate scandals, as well as having been a key factor that contributed to the global financial crisis (e.g., Bebchuk \& Fried, 2005). Consequently, regulators have been concerned that directors should be accountable to shareholders by disclosing their remuneration policies. In particular, the EU Commission $(2004 ; 2009)$ has issued two non-binding recommendations to its country members. Therefore, directors' remuneration disclosure is a topic relevant to both academics and policymakers. It also provides an appropriate setting to examine the disclosure of board practices and investigate potential drivers for providing voluntary disclosure (Laksmana, 2008).

By analysing a sample of 234 size- and industry-paired Italian and UK non-financial listed firms in 2009, this paper achieves two purposes. First, it explores how directors' 
remuneration practices ${ }^{1}$ are disclosed in two major European economies, the UK and Italy, by developing a comprehensive disclosure index. Greater transparency enables shareholders to monitor the relationship between directors' remuneration and firm performance better and to verify whether remuneration is effectively designed to align directors' and shareholders' interests (Craighead et al., 2004; Laksmana 2008; Laksmana et al., 2012). Second, this paper investigates which factors are associated with the level of voluntary disclosure provided by firms. It finds that both country-level and firm-specific factors, such as the demand for information from outside shareholders and the firms' need for legitimacy, are significantly associated with the level of voluntary disclosure of directors' remuneration.

Italy and the UK were chosen because they can be characterised as being at opposite ends of a spectrum. UK firms are considered as having the best practices in Europe (e.g., RiskMetrics, 2009; Ferrarini et al., 2010), while Italian firms have been seen as exemplifying bad practice (La Porta et al., 1998; Patel et al., 2003; Ferrarini et al., 2010). UK listed firms are usually seen as having an agency problem between executives and shareholders (Mallin, 2010), while Italian listed firms are characterized by an agency problem between controlling and outside shareholders (Melis, 2000). These different agency problems might have different influences on disclosure practices (e.g., Patelli \& Prencipe, 2007). While the UK belongs to the common law group of countries, generally characterised by high disclosure, Italy is included in the civil law countries (La Porta et al., 1999), which are characterised as oriented toward "legal compliance", with low disclosure (e.g., Meek \& Thomas, 2004). Finally, Italy and the UK provide a distinct institutional setting in which to study the influence played by shareholders' votes on directors' remuneration disclosure, as they are among the few countries in which listed companies are mandated to let shareholders vote on directors' remuneration ('Say on pay'). However, this shareholder vote on remuneration has mainly an advisory role (UK Company Act 2006, Italian Civil code, art. 2363 bis). 
Our study contributes to the voluntary disclosure literature in four ways.

First, by focusing on directors' remuneration disclosure it examines a voluntary disclosure decision that reflects a potential conflict of interest between directors and outside shareholders (e.g., Bebchuk et al., 2002). By contrast, most of the extant literature focuses on the explanations for disclosure where shareholders' and directors' interests are not likely to be in conflict (e.g., Botosan, 1997; Archambault \& Archambault, 2003; Patel et al., 2003; Prencipe, 2004; Markarian et al., 2007).

Second, this study extends the emerging literature on voluntary disclosure on directors' remuneration (e.g., Byrd et al., 1998; Laksmana, 2008; Schiehll et al., 2013). We developed a more comprehensive disclosure index than those used in previous studies (Laksmana, 2008; Liu \& Taylor, 2008). This covers all the relevant directors' remuneration components, as confirmed by active institutional investors. By contrast, previous studies mainly focused on specific remuneration components, such as share-based remuneration (Liu \& Taylor, 2008; Schiehll et al., 2013), termination payments (Liu \& Taylor, 2008), and remuneration peer groups (Byrd et al., 1998).

Third, by conducting a comparative analysis, this paper explores the potential variation of directors' remuneration disclosure in two major European economies and contributes to the debate on whether voluntary disclosure is associated with country-level characteristics and/or firm-specific factors (e.g., Archambault \& Archambault, 2003; Cheng \& Courtenay, 2006; Durnev \& Kim, 2005; Doidge et al., 2007). It provides new evidence that voluntary disclosure is driven by a combination of institutional and firm-specific factors.

Fourth, by shedding light on directors' remuneration disclosure in European firms, this study contributes to our understanding of the extent to which the findings of previous studies, which mainly focused on US firms (e.g., Byrd et al., 1998; Laksmana, 2008), can be generalised in other institutional settings. This paper shows that previous findings related to 
US firms are mainly confirmed in an institutional setting which shares similar characteristics (e.g. Anglo-American market-oriented setting, like the UK), but are less applicable to a nonAnglo-American institutional setting (e.g. relationship-based setting, like Italy). This result represents an important contribution to the more generic corporate disclosure literature (e.g. Marston \& Shrives, 1991; Botosan, 1997; Giner Inchausti, 1997; Archambault \& Archambault, 2003; Patel et al., 2003; Prencipe; 2004; Cheng \& Courtenay, 2006; Markarian et al., 2007). The demand for information is an important driver for voluntary disclosure only in Anglo-American settings, while its importance in other institutional settings seems to be limited. Although the extent of voluntary disclosure is associated with the search for legitimacy in both institutional settings, this paper shows that the drivers of the need for legitimacy are not universal, but are related to the institutional context a firm operates in.

The rest of the paper is structured as follows. The next section covers the literature review and the development of the hypotheses. We then outline our research methodology, followed by the data analysis and the empirical findings. Concluding remarks, policy implications and limitations of the paper are presented in the final section.

\section{Related literature and hypotheses' development}

According to Verrecchia (2001) a comprehensive theory of voluntary disclosure does not exist, with the only wholly unifying assumption among different theories being that any firm contemplating making a disclosure is likely to disclose information that is favourable to the firm and is unlikely to disclose information that is unfavourable to the firm (Dye, 2001). The incentives to disclose information voluntarily can be explained in terms of economics-based as well as system-based theories (e.g., Cormier et al., 2005; Cotter et al., 2011; Beattie \& Smith, 2012). Those theories are, to an extent, mutually consistent, overlapping and 
potentially complementary (e.g., Cormier et al., 2005; Broberg et al., 2010; Beattie \& Smith, 2012).

Instead of relying on a single theoretical background, we, therefore, adopt multi-theoretical lenses that rely on economic incentives, legitimacy needs and institutional factors to explain the extent of directors' remuneration disclosure.

In providing voluntary disclosure, a firm is subject to three levels of potential influence (Cormier et al., 2005). Senior management is directly accountable towards its investors. Hence, we rely on agency theory to investigate whether managers provide information voluntarily to reduce the information asymmetry with investors. At the same time, a firm operates within a broader societal context and its activities affect a wide range of other stakeholders. Senior management is also accountable towards the society. Hence, firms may disclose voluntary information not only to reduce the information asymmetry, but also to gain and maintain legitimacy in society. Legitimacy theory suggests that the extent of a firm voluntary disclosure is a response to public pressure. In determining voluntary disclosure, corporate insiders consider a firm's institutional context. Organizational practices (such as disclosure practices) do not develop in a vacuum, as firms are embedded in a nexus of formal

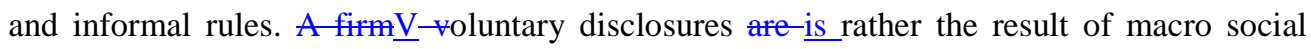
processes (DiMaggio \& Powell, 1983). The needs of a firm for legitimacy depend on the characteristics of the institutional setting in which a firm operates (e.g., Suchman, 1995; Chalmers \& Godfrey, 2004). Similarly, agency theory can incorporate an institutional perspective, thereby giving explicit recognition to the social contexts surrounding agency relations (Wiseman et al 2012). Although agency problems (information asymmetry, conflict of interest, and opportunistic agent behaviour) are universal, the explicit manifestation of these problems (and the ways to deal with them) may vary depending on the institutional context in which a firm operates (Wiseman et al., 2012). Therefore, both country-level 
institutional characteristics and firm-specific factors may influence the level of voluntary disclosure of directors' remuneration. Previous studies which found that firm-specific factors influence corporate disclosure did not take into account potential differences in country-level institutional characteristics (e.g., Botosan, 1997; Giner Inchausti, 1997; Cheng \& Courtenay, 2006; Laksmana, 2008). Therefore, building on previous literature on remuneration disclosure (e.g., Byrd et al. 1998, Laksmana, 2008, Liu \& Taylor 2008; Laksmana et al., 2012; Schiehll et al., 2013), we derive our hypotheses from agency theory and legitimacy theory, adopting both country-level and firm-specific considerations.

\subsection{Voluntary disclosure and country-level institutional characteristics.}

Disclosure practices reflect the underlying environmental influences that affect firms in different countries (e.g., Ball et al., 2000; Haniffa \& Cooke, 2002; Archambault \& Archambault, 2003; Doidge et al., 2007). There are two main corporate systems in developed economies: relationship-based and market-oriented (e.g., Weimer \& Pape, 1999; Clarke, 2007). When compared to the relationship-based system, the market-oriented system is characterized by a relatively large equity market (e.g., La Porta et al., 1999), a higher capital market orientation (e.g., Pagano et al., 1998), and a more active takeover market (Weimer \& Pape, 1999). These characteristics produce a higher need for firms to provide information to 'anonymous' investors at a distance (Ball et al., 2000). As the market needs information, the power of the market depends on information availability. Disclosure is thus one of the cornerstones for effective, market-based control mechanisms. Indeed, Markarian et al. (2007) found that, although disclosure practices have been converging, there are still significant differences in disclosure characteristics across corporate systems. Moreover, firms in marketoriented systems have a higher level of disclosure. 
International taxonomies list Italy as a relationship-based corporate system, while the UK belongs to a market-oriented corporate system (e.g., La Porta et al., 1999; Clarke, 2007). Hence, we expect that:

H1: The extent of voluntary disclosure of directors' remuneration is higher in UK firms than in Italian firms.

\subsection{Voluntary disclosure and firm-specific incentives.}

\subsubsection{Voluntary disclosure and the demand for information.}

Agency theory suggests that the potential for agency costs arises in firms characterised by a separation of ownership and control (Jensen \& Meckling, 1976). In firms with dispersed ownership the potential for conflict between principal and agent is greater than in firms with concentrated ownership. Firms with more dispersed shareholders have a larger number of shareholders who are not directly involved in the management of the firm and, consequently, the agency costs due to information asymmetry between shareholders and corporate insiders are higher (Jensen \& Meckling, 1976). The demand and, therefore, the supply of quality information will be high in firms owned by widely-dispersed shareholders (Kothari, 2001). The annual report is typically the main source of information for such outside shareholders (Lang \& Lundholm, 1996). In contrast to firms with widely-dispersed ownership, the presence of controlling shareholders overcomes some of the principal-agent problems since controlling shareholders have the power to influence the board decision-making process (Melis, 2000). Thus, in such firms, information is mainly transferred from management to controlling shareholders through informal channels rather than via the annual report (Berglöf $\&$ Pajuste, 2005). As a result, disclosure is likely to be greater in widely-held firms (Kothari, 2001) and ownership diffusion is expected to be positively associated with voluntary 
disclosure (Raffournier, 1995; Haniffa \& Cooke, 2002; Prencipe, 2004; Patelli \& Prencipe, 2007; Chizema, 2008). Hence, we expect that:

H2a: The extent of voluntary disclosure of directors' remuneration is positively related to the level of ownership diffusion.

Although the demand for information is higher when ownership is widespread, because of the lack of close monitoring, directors could opportunistically reduce the information disclosed to hide details of their own remuneration packages from shareholders (Bebchuk et al., 2002). The presence of outside shareholders could, however, increase the level of disclosure as such shareholders may have the interest to monitor directors. Unlike the controlling shareholders, outside shareholders are not able to get information via private channels, but need the information to be disclosed in public documents, such as the annual report. Both UK and Italian firms must subject directors' remuneration to a shareholders' vote ('Say on pay') (UK Company Act 2006, Italian Civil code, art. 2363 bis). After analysing the publicly disclosed information, shareholders can give an opinion on directors' remuneration. The demand for information on directors' remuneration is likely to be higher for companies in which outside shareholders are able to vote on the resolution to approve directors' remuneration (Mangen \& Magnan, 2012). Hence, we expect that:

$H 2 b$ : The extent of voluntary disclosure of directors' remuneration is positively related to the level of outside shareholders' attendance at the shareholders' general meeting that approved directors' remuneration. 


\subsubsection{Voluntary disclosure and the need for legitimacy.}

Voluntary disclosure can be provided by firms to achieve legitimacy (e.g., Dowling \& Pfeffer, 1975; Liu \& Taylor, 2008). Legitimacy theory argues that the greater the likelihood of negative social perceptions of a firm's activities, the greater the firm's desire to gain or retain legitimacy. Firms seeking legitimacy try to ensure that they operate within the norms of their respective societies by adopting strategies and practices that conform with societal norms, values, and expectations (Meyer \& Rowan, 1977).

The disclosure of voluntary information in annual reports is an important communication strategy that allows firms, which want to gain or retain legitimacy, to potentially influence public opinion (Dowling \& Pfeffer, 1975). Legitimacy is usually associated with highly contested topics such as social and environmental disclosure (Deegan \& Gordon, 1996; Guthrie \& Parker, 1989; Patten, 1992; Tilt, 1994; Wilmshurst \& Frost, 2000) and derivatives (Chalmers \& Godfrey, 2004). However, firms are also sensitive to stakeholder criticism of remuneration-related issues (e.g., Murphy, 1996). It, therefore, follows that more detailed information on directors' remuneration will be provided by firms to obtain legitimacy (Chizema, 2008; Liu \& Taylor, 2008).

There are several situations that could create greater firm-specific incentives for legitimacy through voluntary disclosure of directors' remuneration. Directors of firms subject to greater public scrutiny are more interested in obtaining and/or retaining legitimacy. The media can create an awareness of legitimacy threatening issues. Companies with negative coverage about a specific issue are likely to respond to this media by providing more public information on the specific issue (e.g., Brown \& Deegan, 1998; Liu \& Taylor, 2008; Laksmana, 2008). Thus, a greater level of media coverage paid to directors' remuneration could lead firms to enhance their level of voluntary disclosure on this issue. Hence, we expect that: 
H3a: The extent of voluntary disclosure of directors' remuneration is positively related to the level of related media coverage on such issue.

Firms with highly-remunerated CEOs are likely to be exposed to public scrutiny. As excessive remuneration has been blamed for being one reason for the recent financial crisis, increases in CEO remuneration could draw external attention to the firm's remuneration policies. Firms which pay high remuneration packages may thus have the incentives to provide more detailed information about directors' remuneration in order to justify not only the level of CEO remuneration but also any increases in CEO remuneration (Wade et al., 1997; Liu et al., 2006). Hence, we expect that:

$\mathrm{H} 3 \mathrm{~b}$ : The extent of voluntary disclosure of directors' remuneration is positively related to the level of CEO remuneration.

H3c: The extent of voluntary disclosure of directors' remuneration is positively related to any increases in the level of CEO remuneration.

Much of the concern with remuneration is driven by shareholders' demands that CEOs should be compensated on the basis of the firm's financial performance (Wade et al., 1997). Poorly-performing firms are subject to greater market pressure as they have eroded shareholders' value. Poorly-performing firms, therefore, need to provide more justification for the remuneration paid to their directors (e.g., Wade et al., 1997). As the media focuses particular attention on listed firms' market performance, to reduce potential negative publicity, poorly performing firms have incentives to provide more disclosure. Hence, we expect that: 
H3d: The extent of voluntary disclosure of directors' remuneration is negatively related to the level of firm's market performance.

Outside shareholders' dissent on remuneration resolutions may cause 'outrage' (Bebchuk et al., 2002; Mangen \& Magnan, 2012). Proposals on directors' remuneration at the shareholders' meeting will draw remuneration to the attention of the shareholders. Therefore, firms have incentives to enhance the level of directors' remuneration disclosure in the annual report so as to reduce potential further 'outrage' (Liu \& Taylor, 2008). Hence, we expect that:

$\mathrm{H} 3 \mathrm{e}:$ The extent of voluntary disclosure of directors' remuneration is positively related to the presence of outside shareholders' dissenting votes on remuneration resolution.

\section{Data and research method}

\subsection{Sample and data gathering}

The sample comprises non-financial Italian and UK firms listed, respectively, on the Milan and London Stock Exchange in 2009. Financial firms were eliminated in view of their sectorspecific peculiarities (e.g., Giner Inchausti, 1997). 2009 was selected because, at the time of data collection, it was the most recent period for which annual reports were available. We identified 235 Italian non-financial firms and 1,528 UK non-financial firms. Fifteen Italian firms and 861 UK firms whose financial year did not end on December 31st were eliminated from the analysis, to assure the comparability of the results, leaving a sample of 220 Italian and 667 UK firms. In order to facilitate comparisons between Italian and UK firms, we matched them pairwise (e.g., Bozzolan et al., 2003). As previous studies found that firm size and industry (Firth, 1979; Cooke, 1989, 1992; Wallace \& Naser, 1995, Raffournier, 1995; Botosan, 1997; Giner Inchausti, 1997; Robb et al., 2001; Owusu-Ansah \& Yeoh, 2005) affect 
the level of voluntary disclosure, the sample was selected so that UK and Italian firms were not significantly different from each other in terms of industry and size. Both sets of firms were classified according to the two-digit SIC code industry and market capitalisation at 3112-2008 (as a proxy for firm size), leaving a final sample of 117 firms for each country (see table 1 for a description of the sample characteristics).

We investigated remuneration disclosure by analysing corporate annual reports, corporate governance reports and, when publicly available, directors' remuneration reports. We also analysed regulatory filings when available. All the above mentioned information was usually part of the annual report.

Data about industry, market capitalisation and financial analysts' coverage were collected from the Thomson One Banker database. Data about ownership diffusion were manuallycollected from annual reports for UK firms and gathered from the Consob database for Italian firms. Market performance, profitability and financial leverage were collected from the Amadeus database. Data about shareholders' attendance and dissenting votes on the remuneration resolution at the shareholder meeting were gathered from the Manifest database for UK firms and were manually-collected from the minutes of the shareholders' meetings for Italian firms. CEO remuneration data was manually-collected from annual reports. Data about media coverage were collected from the Factiva database.

\subsection{Directors' disclosure remuneration: regulatory framework}

Voluntary disclosure is any information not included in legal mandatory requirements (i.e. information disclosed beyond mandatory disclosure requirements in the form of laws, stock exchange listing rules, and/or accounting regulations). In 2009 Italian listed firms were required to provide details on the remuneration received by each director (in terms of salary, benefits in-kind, bonus) and on share-based payments. For share-based payments, they had to 
disclose the amount of options/shares held by each director (at the start and end of the year) and of options which were granted, exercised and had expired during the year as well as the characteristics of all the existing share-based payments. Moreover, they were also required to provide information on the directors' termination payments (TUF ${ }^{2}$, art. 123-bis).

Directors' remuneration disclosure regulation in the UK differs for FTSE and AIM firms.

In 2009, FTSE firms were required to present a directors' remuneration report in which they provided information on directors' remuneration policy, service contract, as well as details of the remuneration received by each director (in terms of salary, bonus, benefit and termination payment) and the characteristics of the pension schemes. They also had to disclose the characteristics of share-based payments granted or exercised during the year and those unexpired at the end of the year.

AIM firms are regulated by specific London Stock Exchange rules that, in 2009, did not regulate disclosure of directors' remuneration. Nor was the Combined Code (2008) applicable to AIM firms. Thus, all information provided in AIM firms' annual reports on directors' remuneration was voluntary ${ }^{3}$.

Both Italian and UK FTSE listed firms were mandated to let shareholders' vote on the directors' remuneration ('Say on pay') (UK Company Act 2006, Italian Civil code, art. 2363 bis). The shareholders' vote had mainly an advisory role, as firms were not mandated to implement the results of the "Say on pay" votes. In the UK, 'Say on pay' was voluntary for AIM firms.

\subsection{Disclosure index}

The extent of disclosure has been measured on a quantitative basis using disclosure indices. Although disclosure is an abstract concept that cannot be measured directly (Marston \& Shrives, 1991), such indices are able to provide an indirect, if subjective, measure of the 
underlying concept. Their validity has been demonstrated not only by the consistent results documented by previous studies on the determinants of the level of disclosure (Ahmed \& Courtis, 1999), but also by specific analyses carried out to assess their validity (Botosan, 1997). A disclosure index is usually constructed as a function of the number of the items provided in the annual reports (e.g., Botosan, 1997; Prencipe, 2004). The absence of an official index for directors' remuneration disclosure did not allow us to use a publicly available ranking. Moreover, evaluations of firm disclosure practices by professional firms, such as Standard and Poor's, are provided upon firm's request, introducing a self-selection bias into the sample (Cheng \& Courtenay, 2006).

We thus used a self-constructed disclosure index (Botosan, 1997, Cheng \& Courtenay, 2006; Patelli \& Prencipe, 2007). We tested the proposed disclosure index for validity (i.e. the ability of the index to truly capture what is intended) and reliability (i.e. the replication of the measurement process) (Cooke and Wallace, 1989; Marston and Shrives, 1991). Following previous studies (e.g., Raffounier, 1995; Patelli \& Prencipe, 2007; Laksmana, 2008), to limit subjectivity, the selection of items included in the directors' remuneration disclosure checklist was guided by the 2004 and 2009 EU non-mandatory recommendations for disclosure, which embrace both Italian and UK firms. The validity of the index was further tested by sending the disclosure index to three leading international institutional investors active in directors' remuneration (Calpers, Hermes, and Standard Life) and discussing with them the relevance of the items to be included. Although institutional investors are not the only stakeholders, information considered relevant for them is also relevant for other stakeholders (IASB, 1989). Validity has been further tested by measuring if there is a significant correlation between the measure adopted (the disclosure index) and an independent, but related, external criterion (Litwin, 1995: 37). In this case, we checked if the disclosure index was correlated with financial analysts' coverage (estimated as the number of 
financial analysts that published at least one report, during the previous financial year, on the firm analysed). Financial analysts' coverage has been proven to have an endogenous relation with a firm disclosure (Brennan \& Subrahmanyam, 1995; Lang \& Lundholm, 1996).

We searched the annual reports (both English and domestic language) for the 67 possible attributes in our disclosure index divided into the following broad categories: a) remuneration policy (4 items); b) design of salary and fees (2 items); c) design of bonus (10 items); d) design of share-based payments (34 items); e) design of pension schemes ( 2 items); f) design of executive contracts and termination payments (3 items); g) remuneration paid to each director (11), and h) the presence of a remuneration section in the annual report (1 item) ${ }^{4}$.

The following procedure was used to score the items: 1 if there was extensive disclosure, 0.5 if it was partially disclosed, zero if it was not disclosed (Robb et al., 2001; Bassett et al., 2007). A not-applicable code (N/A) was adopted when a firm did not disclose an item because there was no reason to disclose it. For example, if the firm disclosed that it did not grant any share-based plan (SBP), we codified the item "No of SBPs granted during the year" as 1 , because the company disclosed the information required. We then considered not applicable for that firm all the items that required details of the SBPs granted during the year ("exercise price", "vesting period" of SBPs granted during the year, etc.) as there is no reason to disclose such information. Not-applicable items were excluded when calculating the maximum possible score (Botosan, 1997; Patelli \& Prencipe, 2007; Teixeira Lopes \& Lima Rodrigues, 2007; Allegrini \& Greco, 2013). Firms were, therefore, not penalised if a disclosure item was not relevant to them. When in doubt, we kept the item. Although this process contains elements of subjectivity, the resulting bias is probably lower than if we had included potentially non-relevant items (Lim et al., 2007; Teixeira Lopes \& Lima Rodrigues, 2007). 
Data collection and analysis were conducted by three researchers. The first phase of data collection involved defining the recording unit. Sentences were chosen as recording units because they were considered more reliable than pages or paragraphs (Hackston \& Milne, 1996). The second phase consisted of defining of a coding procedure to capture directors' remuneration disclosure. A list of identification and classification rules was elaborated defining classification criteria for each item. Explanatory notes on the content of each category-item and examples of sentences to be coded in each category-item were prepared and discussed before the beginning of the analysis (Bozzolan et al., 2003). A preliminary test was conducted to align the set of coding rules among different coders (inter-coder reliability). Six annual reports (three published by Italian firms and three by UK firms) were initially examined independently by three researchers to ensure that the classification criteria were standardised across the researchers. Subsequently, three annual reports were classified independently by two researchers. The results of the individual classifications were compared by the third researcher, who identified misalignments. Discrepancies were re-analysed and resolved by discussion between the three researchers (e.g., Lee, 1999; Markarian et al., 2007). Following this procedure a final set of coding rules was defined. As two coders worked separately, a third researcher assessed the accuracy and consistency of their coding.

The sets of data coded by the two researchers were matched so as to assess the reliability of the coding procedure (inter-coder reliability). Inter-coder reliability was measured by using both the percentage of agreement index (e.g., Markarian et al., 2007) and Cohen's kappa agreement index (Cohen, 1960) in order to overcome the limits intrinsic in each individual index (Lombard et al., 2002).

We computed an index of disclosure (TDI) for each firm, calculated as the ratio of the actual score awarded to the firm $i$ divided by the maximum possible potential score applicable to 
that firm (Raffounier, 1995; Archambault \& Archambault, 2003; Owusu-Ansah \& Yeoh, 2005; Bassett et al., 2007; Lim et al., 2007; Patelli \& Prencipe, 2007). In particular:

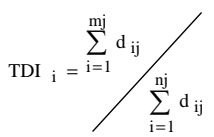

where $\mathrm{TDI}_{\mathrm{i}}$ is the disclosure index of the firm $i ; d_{i j}$ is the value for a disclosure index item $j$, for firm $i ; m_{j}$ is the number of disclosure items which are relevant to firm $i$ and were actually disclosed, and $n_{j}$ is the maximum number of disclosure items that can be disclosed by firm $i$ given the elements in the directors' remuneration package. The total available scores exclude items that are not applicable to an individual firm. This exclusion, together with the proportional score approach, allows comparable disclosure scores to be constructed for each firm (e.g., Bassett et al., 2007).

In similar way to the total disclosure index (TDI), the voluntary disclosure index (VDI) was calculated on the voluntary disclosure items $\left(\mathrm{vd}_{\mathrm{ij}}\right)$ as a proportion of the maximum possible potential score, excluding items not applicable to an individual firm.

The results of the analysis of inter-coder reliability, measured with the percentage of agreement and the Cohen's kappa scores, are above the appropriate minimum acceptable levels (90 percent and 0.8 respectively). Both disclosure indices were also found to be significantly correlated with financial analysts' coverage $(0.35, \mathrm{p}<0.001)$. We can thus conclude that the total and the voluntary disclosure indices are both reliable and valid.

\subsection{Models, dependent and independent variables}

\subsubsection{Models}

In order to contribute to the debate regarding the role of country-level characteristics and firm-specific factors in influencing firms' disclosure, we followed Doidge et al. (2007) and estimated the following hierarchical cross-sectional regression models: 
(1) $\mathrm{VDI}_{\mathrm{i}}=\alpha_{0}+\delta$ Country $_{\mathrm{i}}+\varepsilon_{\mathrm{i}}$

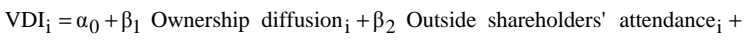

(2) $+\beta_{3}$ Media coverage ${ }_{i}+\beta_{4}$ Ceo remuneration ${ }_{i}+\beta_{5}$ Ceo remuneration change $e_{i}+$

$+\beta_{6}$ Market performance ${ }_{i}+\beta_{7}$ Dissenting votes $_{i}+\gamma$ Control variables ${ }_{i}+\varepsilon_{i}$

$\operatorname{VDI}_{\mathrm{i}}=\alpha_{0}+\beta_{1}$ Ownership diffusion ${ }_{\mathrm{i}}+\beta_{2}$ Outside shareholders' attendance +

(3) $+\beta_{3}$ Media coverage $e_{i}+\beta_{4}$ Ceo remuneration ${ }_{i}+\beta_{5}$ Ceo remuneration change ${ }_{i}+$

(3) $+\beta_{6}$ Market performance ${ }_{i}+\beta_{7}$ Dissenting votes $_{i}+\gamma$ Control variables S $_{i}+$

$+\partial$ Country $_{\mathrm{i}}+\varepsilon_{\mathrm{i}}$

where $i=$ firm; $\beta=$ the coefficient that measures the sensitivity of the voluntary disclosure

Formatted: Not Highlight

index to the firm-level characteristics considered as independent variables; $\gamma=$ the coefficient that measures the sensitivity of the voluntary disclosure index to the firm-level characteristics considered as control variables; and $\delta=$ the coefficient that measures the sensitivity of the voluntary disclosure index to the country-level characteristics.

Following Doidge et al. (2007), we first estimated the importance of country-specific characteristics on voluntary disclosure, by projecting the voluntary disclosure index on the country dummy variable (model 1). Then we estimated the importance of firm-specific characteristics on voluntary disclosure, by analysing the effect of firm-level variables on firm's voluntary disclosure (see model 2). The firm-specific variables used in this model estimate the firm-specific demand for information $(\mathrm{H} 2)$ and need for legitimacy $(\mathrm{H} 3)$ while controlling for several firm-specific factors that have been shown to be significant according to the voluntary disclosure literature. In model 3, we estimated regressions of firm-voluntary disclosure on both sets of country-level and firm-specific characteristics. Building the regression models hierarchically allows us to evaluate whether country-level and firmspecific variables are jointly significant, by comparing the adjusted R-square of the three models.

\section{Comment [LA2]: In}

circumstances/contexts like this there does not need to be a use of the plural. You could check if there are other instances.

You could use 'disclosures' or not refer to firm at all since it's pretty clear that you are referring to firm disclosures by this point in the paper 
In addition, because of the different institutional characteristics of Italy and the UK, we test our hypotheses on the Italian and the UK sub-samples to investigate whether the influence of firm-specific factors is different in the two institutional settings analysed.

\subsubsection{Dependent variable}

The dependent variable is the voluntary disclosure index (VDI):

$V D I_{i}=\sum_{i=1}^{m j} v d_{i j} / \sum_{i=1}^{n j} v d_{i j}$

where $\mathrm{VDI}_{\mathrm{i}}$ is the voluntary disclosure index of the firm $i$; $\mathrm{vd}_{\mathrm{ij}}$ is the value for a voluntary disclosure index item $j$, for firm $i$; $m_{j}$ is the number of voluntary disclosure items which are relevant to firm $i$ and were actually disclosed, and $n_{j}$ is the maximum number of voluntary disclosure items that can be disclosed by firm $i$ given the elements that are included in the directors' remuneration package.

\subsubsection{Independent variables}

To test our hypotheses we use the following independent variables:

Country $=$ a dichotomous variable that equals 1 if the firm is based in the UK, and 0 if it is based in Italy.

Ownership diffusion $=$ the percentage of capital not owned by substantial shareholders (i.e. shareholders who own more than $3 \%$ of the voting capital), calculated at the start of the financial year. Sources: Consob database for Italian firms and annual reports for UK firms.

Outside shareholders' attendance $=$ the percentage of voting shares owned by the outside shareholders (i.e. shareholders who are not either controlling shareholders or directors of the firm) that voted for the remuneration resolution at the previous annual general meeting. 
Sources: minutes of shareholders' meetings for Italian firms and the Manifest database for UK firms.

Media coverage $=$ number of articles related to a firm's directors' remuneration published in the main national newspapers during the previous year. Searches on the Factiva database were performed to identify directors' remuneration-related news (Laksmana, 2008; Liu, Taylor, 2008) on the main national newspapers in Italy (Il Sole 24 Ore, Corriere della Sera, La Repubblica, and La Stampa) and the UK (Financial Times, The Time, The Guardian, and The Daily Telegraph) ${ }^{5}$. Source: Factiva database.

$C E O$ remuneration $=$ total amount of remuneration the $\mathrm{CEO}$ received in the previous financial year. Source: firms' annual reports.

$C E O$ remuneration change $=$ the percentage variation of the remuneration the CEO received in the year analysed compared with that received in the previous financial year. Source: firms' annual reports.

Market performance $=$ the percentage variation of the share value at the start of the financial year compared with the share value at the start of the previous financial year. Source: Amadeus database.

Dissenting votes $=$ a dichotomous variable that equals 1 if there was at least one outside shareholder who either abstained or voted against the remuneration resolution at the previous annual general meeting and 0 otherwise. Sources: minutes of shareholders' meetings for Italian firms and Manifest database for UK firms.

\subsubsection{Control variables}

A review of the literature on voluntary disclosure led to the decision to include the following control variables in the multiple regression models for testing our hypotheses: 
- Firm size. Larger firms provide more extensive disclosure than smaller firms as they are more likely to face political costs and have superior information systems to invest in corporate reporting and consequent disclosure (e.g., Cooke, 1989, 1992; Wallace \& Naser, 1995, Giner Inchausti, 1997; Byrd et al., 1998; Robb et al., 2001; Owusu-Ansah \& Yeoh, 2005). This was measured as the market capitalization of the firm at the start of the financial year. Source: Thomson One Banker database.

- Profitability. The level of firms' profitability may influence the level of disclosure of directors' remuneration as most remuneration schemes are based heavily on profitability (Murphy, 1999). Profitability was estimated as the Return on Assets (ROA) at the end of the previous financial year. Source: Amadeus database.

- Financial leverage. Firms with higher leverage typically have higher agency costs and may attempt to reduce these costs through increased disclosure (Jensen \& Meckling, 1976). However, the agency problem and the consequent need to disguise remuneration packages might reduce the level of disclosure of directors' remuneration (Bebchuk et al., 2002). This equals the percentage ratio of the value of total debts to total assets at the start of the financial year. Source: Amadeus database.

- Remuneration complexity. Firms with complex directors' remuneration structures are more prone to potential disclosure problems, thus they are more likely to have additional deficiencies in disclosure (Robinson et al., 2011). It was measured as the total number of items applicable to the firm analysed divided by the total number of items in the index.

- Industry. The industrial sector that a firm operates in may influence that firm disclosure policy, either because of industry-related, peer-influence or the need to conform to market expectations (e.g., Cooke, 1992; Botosan, 1997; Robb et al., 2001). Firms were, therefore, classified by using the one-digit SIC code. Source: Thomson One Banker database. 
- AIM $^{6}$. AIM and FTSE firms are subject to different disclosure regulations. Thus, we considered whether the firm was listed on the AIM. The AIM variable is dichotomous and equals 1 if the firm was listed on the AIM and 0 otherwise.

\section{Results}

\subsection{Descriptive statistics on firm's characteristics}

Table 1 summarises the main characteristics of the Italian and UK firms analysed.

\section{INSERT TABLE 1}

By comparison with UK firms, Italian firms have a significantly lower level of remuneration complexity, with fewer items to be disclosed. This probably reflects the different ownership and control structure of the two countries, which, in turn, leads to remuneration playing a different role in reducing the agency problem. Italian firms have a more concentrated ownership structure. Outside shareholders' meeting attendance and the presence of dissenting votes are significantly higher in UK firms. UK firms increase CEO compensation more than Italian firms, have a higher profitability and are followed by a higher number of financial analysts. There are only UK firms listed on the $\mathrm{AIM}^{7}$.

\subsection{Findings on overall disclosure}

Our findings show that UK FTSE firms provide a higher level of total disclosure of directors' remuneration $(\mathrm{TDI}=0.75)$ than UK AIM firms $(\mathrm{TDI}=0.47)$ and Italian firms $(\mathrm{TDI}=0.56)$. The total level of disclosure provided in both countries does not allow annual reports' users to get a comprehensive picture of directors' remuneration in terms of incentive mechanisms and the potential relationship between remuneration and performance. Users' ability to evaluate remuneration arrangements is, thus, limited (see table 2). 


\section{INSERT TABLE 2}

Overall, there is extensive disclosure on the amount of remuneration paid to each director. In terms of remuneration policy, both Italian and UK firms provide information on the general policy adopted to pay directors (in both countries the average level of disclosure for this item is higher than 0.90) and on the link between pay and performance (in both countries the average level of disclosure for this item is close to 0.90). However, the relative importance of variable remuneration as compared to fixed remuneration is widely disclosed only by UK FTSE firms, which provide an average level of disclosure of 0.85 . By contrast, the average level of disclosure for this item is less than 0.43 for Italian firms, and 0.07 for UK AIM firms. In both countries, firms provided little information about the peer-firms considered when setting up remuneration agreements. Indeed such information is never disclosed by Italian firms, and the average level of disclosure is 0.19 for UK FTSE firms and 0.02 for UK AIM firms. Scant disclosure also exists on the details of fees payable to directors for the roles held within the board. This was disclosed most by UK FTSE firms (the average level of disclosure for this item equals 0.43 ), followed by Italian firms (the average level of disclosure is less than 0.29) and UK AIM firms (the average level of disclosure equals 0.04).

We found important differences in the disclosure of the criteria adopted when deciding on the remuneration components. Italian firms more commonly provide details on the design of termination payments; while UK FTSE firms disclosed more information on the design of salaries, share-based payments, bonus schemes and pension plans.

Share-based payments were generally properly disclosed given the stringent regulatory requirements. By contrast, we found a considerably lower level of disclosure on bonuses in both countries. In particular, UK firms rarely disclosed their performance targets or the amount that directors can earn for each target level on bonus schemes (the average level of disclosure is less than 0.09). However, such items are generally disclosed for share-based 
payments (the average level of disclosure is more than 0.90 for UK FTSE firms and around 0.40 for AIM firms). Italian firms which gave bonuses provided limited information on the measures adopted to estimate directors' performance (the average level of disclosure is less than 0.28$)$. However, such information is generally disclosed by Italian firms for share-based payments (the average level of disclosure is respectively more than 0.65 ).

\subsection{Descriptive findings on voluntary disclosure and multivariate analysis}

Table 3 reports the descriptive statistics about the voluntary disclosure index for Italian and UK firms.

\section{INSERT TABLE 3}

As reported in table 2 (paragraph 4.2), the most significant differences between Italian and UK firms concern items whose disclosure is fully voluntary (such as the design of salaries and bonus schemes and the peer-firms considered when setting-up remuneration policies). Table 3 reports that the level of voluntary disclosure of directors' remuneration is significantly higher in the UK than in Italy $(0.466$ vs. $0.246, \mathrm{p}<0.001)$. The levels of the voluntary disclosure index and the differences between the two countries are also similar when we compare and contrast UK FTSE firms with their Italian counterparts (0.465 vs. 0.247, $\mathrm{p}<0.001)$, and UK AIM firms with their Italian counterparts (0.466 vs. 0.243 , p < $0.001)$.

Table 4 reports the correlations between all the variables used in the analysis for the full sample (Panel A) the Italian sub-sample (Panel B) and the Italian sub-sample (Panel C). Some significant and highly correlated coefficients have been found between the independent variables. In particular, in the full sample the variables Country and Ownership Diffusion are highly positively correlated at 0.73 , while in the UK sample the variables Outside shareholders' attendance, Dissenting votes and AIM are highly correlated between each other 
at nearly $|0.80|$. Despite the presence of these high correlations, multicollinearity is unlikely to be a concern as the VIF values (see table 5) are lower than 5 (Gujarati, 2003; Baum, 2006). Moreover, the series of additional analyses that have been done to address this issue (see $\mathrm{p}$. 28) give us the confidence that our results are not affected by the potential presence of multicollinearity.

\section{INSERT TABLE 4}

Table 5 reports the results of the regression analyses performed in order to test the hypotheses. Model 1 estimates the influence on the voluntary disclosure of the variable country (used to test hypothesis H1). Model 2 estimates the influence on the voluntary disclosure index of the independent firm-specific variables of interest, used to test the set of hypotheses $\mathrm{H} 2$ and $\mathrm{H} 3$, after controlling for other firm-specific variables. Model 3 analyses the joint effect of country-level and firm-specific variables. Model 4 and model 5 consider the effect of independent and control firm-specific variables on voluntary disclosure respectively in the Italian sub-sample and in the UK sub-sample.

\section{INSERT TABLE 5}

We found that country-level institutional characteristics have a significant influence in explaining the level of firms'-voluntary disclosure. Hence, hypothesis 1 is supported: the extent of voluntary disclosure on directors' remuneration is significantly higher in UK firms than in Italian firms. This is consistent with the different market orientation that characterises the UK corporate system and the Italian corporate system.

After controlling for country-level institutional characteristics, we found that firm-specific incentives also have a significant influence on voluntary disclosure. The comparison between the adjusted $\mathrm{R}^{2}$ of model $1(0.29)$ and the adjusted $\mathrm{R}^{2}$ of model $3(0.45)$ shows that adding firm-specific variables increases the explanatory power provided by country-level characteristics. Firm-specific demand for information and firm-specific need of legitimacy 
have a significant influence on the level of voluntary disclosure. However, the intensity of the influence played by such firm-specific variables on voluntary disclosure differs significantly between the two institutional settings analysed (see models 4 and 5 in table 5).

Firm-specific demand for information significantly influences voluntary disclosure in the UK, but not in Italy. As shown in models 4 and 5, hypothesis H2a is supported only in the UK. UK firms with greater ownership diffusion disclose more voluntary information. This result is in line with agency theory, as UK firms are characterised by higher information asymmetry between directors and shareholders than Italian firms. Conversely, we found no significant support to hypothesis $\mathrm{H} 2 \mathrm{~b}$ as the coefficient of outside shareholders' attendance is positive and significant only when the two institutional settings are jointly analysed (see model 3), while it is still positive but not significant when Italian and UK firms are analysed separately (see models 4 and 5).

Our results provide evidence that the need for legitimacy leads Italian and UK firms to disclose higher levels of voluntary information. The relationship between the need for legitimacy and voluntary disclosure depends on the country-level institutional characteristics. In Italy, it is the level of media coverage that prompts voluntary disclosure (H3a). By contrast, in the UK, firms are more likely to disclose more when they are poor market performers and/or there are dissenting votes on remuneration resolution (H3d and $\mathrm{H} 3 \mathrm{e})$. $\mathrm{H} 3 \mathrm{~b}$ and $\mathrm{H} 3 \mathrm{c}$ are not supported. Neither the level of CEO remuneration nor its change seem to play a significant influence on voluntary disclosure.

In addition, we found that firms with a lower level of remuneration complexity and AIM firms have a higher voluntary disclosure index.

\subsubsection{Additional analyses}

In order to control for the robustness of our results, we performed some additional analyses. 
First, as our dependent variable is censored we used the TOBIT regression model instead of the OLS model. Results are consistent with those reported in table 5.

Second, because previous studies (e.g., Cheng \& Courtenay, 2006; Laskmana, 2008, Allegrini \& Greco, 2013) found that board governance is positively associated with voluntary disclosure, we also consider variables that estimate board independence in our model. In particular, we added the following variables to models 2, 3, 4 and 5: board independence (percentage of independent directors on the board at the end of the previous year), CEO duality (equals 1 if the CEO is also the chair at the end of the previous year, and 0 otherwise) and Institutional investors' ownership (percentage of voting shares owned by institutional investors at the end of the previous year). These three governance variables do not seem to play any significant influence on voluntary disclosure.

Third, as remuneration complexity is different between UK FTSE, UK AIM and Italian firms, we run a regression by considering only the Italian firms that have variable remuneration (i.e. share-based remuneration and/or bonuses) and their UK counterparts. Our results are consistent with those reported in table 5 .

Fourth, because UK listed firms are subject to different listing rules when they are listed on the AIM, rather than on the FTSE, we perform our regression models, excluding AIM firms and their Italian counterparts. This does not affect our findings. We then performed a full interactive regression model $\left({ }^{8}\right)$ that allows to take into account the potential moderating role of country-level factors on the relationship between firms'-voluntary disclosure and the firmspecific variables used to test our hypotheses on the demand for information $(\mathrm{H} 2)$ and the need for legitimacy (H3). Consistently with the results reported in table 5, this analysis supports our main findings. The influence played by the firm-specific demand for information and the firm-specific need for legitimacy on voluntary disclosure is moderated by the institutional context. 
Fifth, in order to address the potential concerns about multicollinearity in the UK sub-sample (because of the high correlation between the variables Outside shareholders' attendance, dissenting votes and AIM), we performed three additional regression analyses in which we dropped two of the highly correlated variables. In the first analysis, we dropped the variables Dissenting votes and AIM, in the second the variables Outside shareholders' attendance and AIM, and in the third analysis the variables Outside shareholders' attendance and Dissenting votes. Consistently with the results reported in table 5, the coefficient of ownership diffusion and dissenting votes are still positive and significant and the coefficient of market performance is negative and significant.

Finally, our study relies on a standard OLS regression approach in which variables are assumed to be exogenously determined. As some of the variables (e.g. voluntary disclosure and ownership diffusion) might be endogenously determined, we assessed whether or not interaction exists between such variables, by using a Hausman test. We did not find any evidence of endogeneity. Such a result is in line with the arguments of La Porta et al. (1999) and Liu and Magnan (2011): ownership structures in European countries are relatively stable over time.

\section{Discussion and conclusions}

This paper contributes to the academic disclosure literature (e.g., Marston \& Shrives, 1991; Botosan, 1997; Giner Inchausti, 1997; Archambault \& Archambault, 2003; Patel et al., 2003; Prencipe; 2004; Cheng \& Courtenay, 2006; Markarian et al., 2007) by analysing a disclosure decision that reflects a potential conflict of interest between directors and outside shareholders. It extends the limited, but emerging, literature on directors' remuneration disclosure (Chizema, 2008; Liu \& Taylor, 2008; Laksmana, 2008; Laksmana et al., 2012) by exploring how and to what extent Italian and UK listed firms disclose directors' remuneration 
practices. It also investigates whether country-level institutional characteristics and firmspecific incentives, such as the demand for information from investors and the need for legitimacy, are associated with the level of voluntary disclosure.

Our findings support the arguments that firm's behaviour is a combination of 'idiosyncratic utility functions' with functions that are 'socially imposed' (Wiseman et al., 2012) and that voluntary disclosure is multidimensional and driven by complementary forces (e.g., Cormier et al., 2005).

In line with previous literature (e.g., Archambault \& Archambault, 2003; Markarian et al., 2007), we find that the extent of voluntary disclosure on directors' remuneration is associated with country-level institutional characteristics: voluntary disclosure is significantly higher in the UK than in Italy. This may be due to the different market-orientation and the fact that in the UK executive remuneration has been the subject of scrutiny since the 1990s (e.g. Cadbury Report, 1992; Greenbury Report, 1995), while in Italy such scrutiny has emerged only in the last decade (Ferrarini et al., 2009).

This study also contributes to the voluntary disclosure literature related to firm-specific incentives (e.g., Botosan, 1997; Laksmana, 2008; Liu \& Taylor, 2008). In particular, we find support for agency and legitimacy theories. Voluntary disclosure is positively related to the level of ownership diffusion in the UK, but not in Italy, given the different agency problems that characterise Italian firms. Both UK and Italian firms provide more detailed information on directors' remuneration when they have a higher need for legitimacy. These findings provide new evidence that legitimacy arguments may be extended to voluntary disclosure issues that are highly contested, although not necessarily related to social and environmental issues (Chalmers \& Godfrey, 2004; Chizema, 2008; Liu \& Taylor, 2008).

It is worth noting that firm-specific incentives to disclose information differ according to the institutional setting in which a firm operates. In a market-oriented corporate system, such as 
the UK, incentives mostly come from market pressures (such as the firm's ownership diffusion, market performance and shareholders' dissent). By contrast, in a relationship-based corporate system, such as Italy, market performance is unlikely to influence firms' strategic decisions (Brunello et al. 2003) and firm-specific incentives seems to be represented by the media. Media could affect firms' reputation and compromise their relational capital.

Last but not least, our findings suggest that the disclosure provided in both countries does not allow an annual report's user to get a comprehensive picture about directors' remuneration, in terms of incentive mechanisms and the potential relationship between remuneration and performance (Bebchuk \& Jackson, 2005). Bonuses, an important element of directors' remuneration, are poorly disclosed in both countries. In contrast with share-based payments, which were generally properly disclosed and whose disclosure was mainly mandatory, disclosure on bonuses is mainly voluntary. Information could easily be provided, as the design of bonuses packages is less complex than the design of share-based payments. Full disclosure about all relevant items needs to be required, otherwise firms may design their directors' remuneration packages in accordance to what it is (and what it is not) required to be disclosed (Bebchuk et al, 2002). We, therefore, recommend policymakers to mandate a detailed disclosure for bonus schemes in the same way, as for share-based payments. Moreover, we recommend that it should be mandatory for listed firms to disclose all relevant information about directors' remuneration. This need has been partly recognised by the Italian policymaker that has mandated additional disclosure since 2012. Additional disclosure has also been mandated for AIM firms since 2010. However, further improvement seems to be needed.

We acknowledge that this study has some limitations which, in turn, suggest opportunities for future research. First, we examine directors' remuneration disclosure in two countries and while we are able to leverage the generalisability of our findings thanks to the different 
institutional characteristics of the two countries, a more comprehensive portrait would be obtained by studying additional countries. Second, our sample examines disclosure for a single year in which firms were severely hit by the global financial crisis. This choice enhances internal validity, but consequently treats disclosure as a static concept. Future studies could encompass a longitudinal dynamic model in which variation in disclosure could be associated to variation in the disclosure drivers. They could also investigate whether the level of disclosure and the disclosure drivers are influenced by the global economic cycle. Third, although we used lagged variables and the standard diagnostic procedure did not show any evidence of endogeneity, our study might not perfectly account for any potentially endogenous relations. However, this limitation is common to the whole disclosure literature (e.g., Palepu \& Healy, 2001; Bassett et al, 2007; Teixeira Lopes \& Lima Rodrigues, 2007; Patelli \& Prencipe, 2007, Liu \& Taylor, 2008; Laksmana et al., 2012). Last, but not least, our study focused on the level of disclosure provided by firms, but not whether (and how) firms 'managed' remuneration disclosures, through impression management techniques (Laksmana et al, 2012; Mangen \& Magnan, 2012). Further comparative research might address this issue.

\footnotetext{
Notes

${ }^{1}$ Directors' remuneration comprises both executive and non-executive remuneration. This paper considers the disclosure of both. However, given the material difference in the overall amounts generally paid to executive and non-executive directors, concerns about directors' disclosure are usually about executive directors' remuneration. See table 2 for a full list of items considered.

${ }^{2}$ TUF (acronym for "Testo Unico sulla Finanza") is the Italy's Company act that regulates listed firms.

${ }^{3}$ AIM companies were required to provide information on the aggregate remuneration of directors and on the remuneration of the highest paid director, when such remuneration was equal or higher than $£ 200,000$.

${ }^{4}$ The full list of items that construct the disclosure index is reported in table 2 . The rules of codification are available from the authors upon request.

${ }^{5}$ We made the following query into the database:
} 
COMPANY NAME and director* and compensation OR COMPANY NAME and director* and remuneration OR COMPANY NAME and director* and bonus* OR COMPANY NAME and director* and "stock option*" OR COMPANY NAME and director* and "share award*" OR COMPANY NAME and director* and "CEO pay" OR COMPANY NAME and director* and "director* pay" OR COMPANY NAME and director* and "executive* pay" OR COMPANY NAME and director* and "termination payment*" OR COMPANY NAME and director* and "restricted share*" OR COMPANY NAME and executive* and compensation OR COMPANY NAME and executive* and bonus* OR COMPANY NAME and executive* and remuneration OR COMPANY NAME and executive* and "stock option*" OR COMPANY NAME and executive* and "share award*" OR COMPANY NAME and executive* and "restricted share*" OR COMPANY NAME and executive* and "CEO pay" OR COMPANY NAME and executive* and "director* pay" OR COMPANY NAME and executive* and "executive* pay" OR COMPANY NAME and executive* and "termination payment*" OR COMPANY NAME and CEO and compensation OR COMPANY NAME and CEO and remuneration OR COMPANY NAME and CEO and bonus* OR COMPANY NAME and CEO and "stock option*" OR COMPANY NAME and CEO and "CEO pay" OR COMPANY NAME and CEO and "director* pay" OR COMPANY NAME and CEO and "executive* pay" OR COMPANY NAME and CEO and "termination payment*" OR COMPANY NAME and CEO and "share award*" OR COMPANY NAME and CEO and "restricted share*" OR COMPANY NAME and compensation OR COMPANY NAME and remuneration OR COMPANY NAME and bonus* OR COMPANY NAME and "stock option*" OR COMPANY NAME and "CEO pay" OR COMPANY NAME and "director* pay" OR COMPANY NAME and "executive* pay" OR COMPANY NAME and "termination payment*" OR COMPANY NAME and "share award*" OR COMPANY NAME and "restricted share*".

${ }^{6}$ We considered AIM as control variable only in the UK sub-sample as there was no AIM in Italy at the time of the analysis.

${ }^{7}$ This is because the AIM has been established in Italy only in 2012.

${ }^{8}$ The model used is:

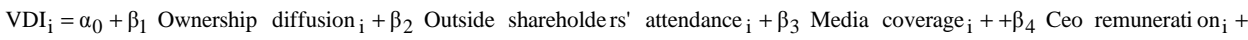

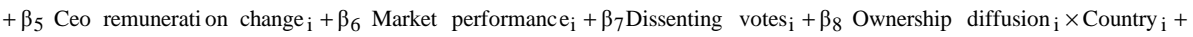

$+\beta_{9}$ Outside shareholde rs' attendance ${ }_{i} \times$ Country $_{i}+\beta_{10}$ Media coverage $_{i} \times$ Country $_{i}+\beta_{11}$ Ceo remunerati on ${ }_{i} \times$ Country $_{i}+$

$+\beta_{12}$ Ceo remunerati on change ${ }_{i} \times$ Country $_{i}+\beta_{13}$ Market performance $_{i} \times$ Country $_{i}+\beta_{14}$ Dissenting $_{\text {votes }} \times$ Country $_{i}+$

$+\gamma$ Control variables $_{i}+\partial$ Country $_{i}+\varepsilon_{i}$ 


\section{References}

Ahmed, K., Courtis, J. (1999). Associations between corporate characteristics and disclosure levels in annual reports: a meta-analysis. British Accounting Review, 31(1), 35-61.

Allegrini, M., Greco, G. (2013). Corporate boards, audit committees and voluntary disclosure: evidence from Italian Listed Companies, Journal of Management and Governance,17(1), 187216 .

Archambault J., Archambault M., (2003). A multinational test of determinants of corporate disclosure. International Journal of Accounting, 38(2), 173-194.

Ball, R., Kothari, S. Robin, A. (2000). The effect of international institutional factors on properties of accounting earnings, Journal of Accounting and Economics, 29(1), 1-51.

Bassett, M., Kohb, P., Tutticci, I. (2007). The association between employee stock option disclosures and corporate governance: Evidence from an enhanced disclosure regime. The British Accounting Review, 39(4), 303-322.

Baum, C. (2006). An Introduction to Modern Econometrics Using Stata. College Station, TX: Stata Press.

Beattie V. \& S. Smith (2012), Evaluating disclosure theory using the views of UK finance directors in the intellectual capital context, Accounting and Business Research, 42(5), 471-494.

Bebchuk, L., Fried, J., (2005). Executive Remuneration at Fannie Mae: A Case Study of perverse Incentives Nonperformance Pay, and Camouflage, The Journal of Corporation Law, 30(4), 807822.

Bebchuk, L., Fried, J., Walker, D. (2002). Managerial Power and Rent extraction in the Design of Executive Remuneration, University of Chicago Law Review, 69, 751-846.

Bebchuk, L., Jackson, R. (2005). Executive pensions, The Journal of Corporation Law, 30(4), 823855

Berglöf, E., Pajuste, A. (2005). What do Firms Disclose and Why? Enforcing Corporate Governance and Transparency in Central and Eastern Europe, Oxford Review of Economic Policy, 21(2), 178-197.

Botosan, C. (1997). Disclosure level and the cost of equity capital. The Accounting Review, 72(3), 323-349.

Bozzolan, S., Favotto, F., Ricceri, F. (2003). Italian intellectual capital disclosure. An empirical analysis, Journal of Intellectual Capital, 4(4), 543-558.

Broberg P., Tagesson T., Collin S. (2009), What explains variation in voluntary disclosure? A study of the annual reports of corporations listed on the Stockholm Stock Exchange. Journal of Management and Governance, 14(4), 351-377.

Brown, N., Deegan, C. (1998). The public disclosure of environmental performance informationa dual test of media agenda setting theory and legitimacy theory, Accounting and Business Research, 29(1), 21-41. 
Brunello, G., Graziano, C., Parigi, B. (2003). CEO turnover in insider-dominated boards: The Italian case, Journal of Banking and Finance, 27, 1027-1051.

Byrd, J., Johnson, M., Porter, S. (1998). Discretion in Financial Reporting: The Voluntary Disclosure of Compensation Peer Groups in Proxy Statement Performance Graphs, Contemporary Accounting Research, 15(1), 25-52.

Cadbury, A. (1992). Report of the Committee on the Financial Aspects of Corporate Governance, London: Gee.

Chalmers, K., Godfrey, J. (2004). Reputation costs: the impetus for voluntary derivative financial instrument reporting, Accounting, Organizations and Society, 29(2), 95-125.

Cheng, E., Courtenay, S. (2006). Board composition, regulatory regime and voluntary disclosure, The International Journal of Accounting, 41(3), 262-289.

Chizema, A. (2008). Institutions and Voluntary Compliance: The Disclosure of Individual Executive Pay in Germany, Corporate Governance: An International Review, 16(4), 359-374.

Clarke, T. (2007). International Corporate governance. A comparative approach, London: Routledge.

Cohen, J. (1960). A coefficient of agreement for nominal scales, Educational and Psychological Measurement, 20(1), 37-46.

Combined Code (2008). The Combined Code on Corporate Governance, London: FRC.

Cooke, T. (1989). Disclosure in the corporate annual reports of Swedish companies, Accounting and Business Research, 19(74), 113-24.

Cooke, T. (1992). The impact of size, stock market listing and industry type on disclosure in the annual reports of Japanese listed corporations, Accounting and Business Research, 22(87), 22937.

Cooke, T., Wallace, R. (1989). Global survey of corporate disclosure practices and audit firm: a review essay, Accounting and Business Research, 19 (Winter), 47-57.

Cormier, D., Magnan, M., \& Van Velthoven, B. (2005). Environmental disclosure quality in large German companies: Economic incentives, public pressures or institutional conditions? European Accounting Review, 14(1), 3-39.

Cotter, J., Lokman, N., Najah M. (2011), Voluntary disclosure research: Which theory is relevant?, The Journal of Theoretical Accounting Research, 6(2), 77-95.

Craighead, J., Magnan, M., Thorne, L. (2004). The impact of mandated disclosure on performancebased CEO remuneration, Contemporary Accounting Research, 21(2), 369-398.

Deegan, C., Gordon, B. (1996). A study of the environmental disclosure practices of Australian corporations, Accounting and Business Research, 26(3), 187-199.

DiMaggio, P., Powell, W. (1983). The iron cage revisited: institutional isomorphism and collective rationality in organizational fields, American Sociological Review, 48(2), 147-160. 
Doidge, C., Karolyi, A., Stulz, R. (2007). Why do countries matter so much for corporate governance?, Journal of Financial Economics, 86(1), 1-39.

Dowling, J., Pfeffer, J. (1975). Organizational legitimacy: Social Values and Organizational Behavior. The Pacific Sociological Review, 18(1), 122-136.

Durnev, A., Han Kim, E. (2005). To Steal or Not to Steal: Firm Attributes, Legal Environment, and Valuation. Journal of Finance, 60(3), 1461-1493.

Dye, R. (2001), An evaluation of "essays on disclosure" and the disclosure literature in accounting, Journal of Accounting and Economics, 32, 181-235.

EU Commission (2004). Fostering an appropriate regime for the remuneration of directors of listed companies, Brussels.

EU Commission (2009). Complementing Recommendations 2004/913/EC and 2005/162/EC as regards the regime for the remuneration of directors of listed companies, Brussels.

Ferrarini, G., Moloney, N., Ungureanu, M. (2009). Understanding Directors' Pay in Europe: A Comparative and Empirical Analysis, ECGI - Law Working Paper No. 126, available on the internet at http://papers.ssrn.com/sol3/papers.cfm?abstract_id=1418463.

Ferrarini, G., Moloney, N., Ungureanu, M. (2010). Executive Remuneration in Crisis: A Critical Assessment of Reforms in Europe, Journal of Corporate Law Studies, 10(1), 73-118.

Firth, M. (1979). The impact of size, stock market listing, and auditors on voluntary disclosure in corporate annual reports, Accounting and Business Research, 9, Autumn, 273-280.

Giner Inchausti, B. (1997). The influence of company characteristics and accounting regulation on information disclosed by Spanish firms, European Accounting Review, 6(1), 45-68.

Greenbury Report (1995). Directors' Remuneration. Report of a study group chaired by Sir Richard Greenbury, July. London: Gee.

Gujarati, D. (2003). Basic Econometrics. New York: McGraw Hill.

Guthrie, J., Parker, L. (1989). Corporate social reporting: a rebuttal of legitimacy theory, Accounting and Business Research, 19(76), 343-352.

Hackston,. D., Milne, M. (1996) Some Determinants of Social and Environmental Disclosures in New Zealand Companies, Accounting, Auditing and Accountability Journal, 9(1), 77-108.

Haniffa, R., Cooke, T. (2002). Culture, corporate governance and disclosure in Malaysian corporations, Abacus, 38(3), 317-349.

Healy, P., Papelu, K. (2001). Information asymmetry, corporate disclosure, and the capital markets: A review of the empirical disclosure literature, Journal of Accounting and Economics, 31(1-3), 405-440.

International Accounting Standards Board (1989). Framework for the Preparation and Presentation of Financial Statements. London: IASCF.

Italian Corporate Governance Code, (2006). Milan: Borsa Italiana. 
Jensen, M., Meckling, W. (1976). Theory of the firm: management behavior, agency costs and ownership structure. Journal of Financial Economics, 3(4), 305-360.

Jensen, M., Murphy, K., Wruck, E. (2004). Remuneration: Where we've been, how we got to here, what are the problems, and how to fix them, ECGI Finance Working Paper N. 44.

Kothari, S.P. (2001). Capital market research in accounting, Journal of Accounting and Economics, $31(1-3), 105-231$

La Porta, R., Lopez-de-Silanes, F., Shleifer, A., Vishny, R. (1998). Law and Finance. Journal of Political Economy, 106, 1113-1155.

La Porta, R., Lopez-de-Silanes, F., Shleifer, A., Vishny, R. (1999), Corporate ownership around the world. Journal of Finance, 54, 471-517.

Laksmana, I. (2008). Corporate Board Governance and Voluntary Disclosure of Executive Remuneration Practices, Contemporary Accounting Research, 25(4), 1147-1182.

Laksmana, I., Tietz, W., Yanget, Y. (2012). Compensation discussion and analysis (CD\&A): Readability and management obfuscation, Journal of Accounting and Public Policy, 31(2), 185203.

Lang, M., Lundholm, R. (1996). Corporate disclosure policy and analyst behavior. The Accounting Review, 71(4), 467-493.

Lee, T. (1999). Using Qualitative Methods in Organizational Research, Thousand Oaks, CA: Sage.

Lim, S., Matolcsy, Z., Chow, D. (2007). The Association between board composition and different types of voluntary disclosure, European Accounting Review, 16(3), 555-583.

Litwin, M. (1995). How to Measure Survey Reliability and Validity. London: Sage.

Liu, J., Taylor, D. (2008). Legitimacy and corporate governance determinants of executives' remuneration disclosures, Corporate governance, 8(1), 59-72.

Liu, J., Taylor, D., Harris, K. (2006). Legitimacy and Corporate Governance Determinants of the Disclosure of Executives' Share Rights, Options and Termination Benefits, ICAFT 2006 Conference Proceedings.

Liu, M., Magnan, M. (2011), Self-dealing Regulations, Ownership Wedge, and Corporate Valuation: International Evidence, Corporate Governance: An International Review, 19(2), 99115.

Lombard, M., Snyder-Duch, J., Bracken, C. (2002). Content analysis in mass communication: Assessment and reporting of intercoder reliability, Human Communication Research, 28(4), 587-604.

Mallin, C. (2010). Corporate Governance, Oxford: Oxford University Press.

Mangen, C., Magnan, M. (2012). Say on Pay: A wolf in sheep's clothing? Academy of Management Perspectives, 26(2), 86-104. 
Markarian, G., Parbonetti, A., Previts, G. (2007). The Convergence of Disclosure and Governance Practices in the World's Largest Firms, Corporate Governance: An International Review, 15(2), 294-310.

Marston, C.L., Shivres, P.J. (1991). The use of disclosure indices in accounting research: a review article. British Accounting Review, 23(3), 195-210.

Meek, G., Thomas, W. (2004). A review of markets-based international accounting research. Journal of International Accounting Research, 3(1), 21-41.

Melis, A. (2000). Corporate governance in Italy. Corporate Governance: An International Review, $8(4), 347-355$.

Meyer, J., Rowan, B. (1977). Institutional organizations: formal structure as myth and ceremony, American Journal of Sociology, 83, 340-363.

Murphy, K. (1996). Reporting Choice And The 1992 Proxy Disclosure Rules, Journal of Accounting, Auditing and Finance, 11(3), 497-515.

Murphy, K. (1999), Executive compensation, In O. Ashenfelter and D. Card (Eds), Handbook of Labor Economics (pp. 2485-2563) North Holland: Amsterdam.

Nelson, J., Gallery, G., Percy, M. (2010). Role of corporate governance in mitigating the selective disclosure of executive stock option information. Accounting and Finance, 50(3), 685-717.

Owusu-Ansah, S., Yeoh, J. (2005). The effect of legislation on corporate disclosure practices. Abacus, 41(1), 92-109.

Pagano, M., Panetta, F., Zingales, L. (1998). Why do companies go public? An empirical analysis, Journal of Finance, 53(1), 27-64.

Patel, S., Balic A., Bwakira, L., Bradley, N., Dallas, G. (2003). Transparency and Disclosure Study: Europe, Standard \& Poor's, April.

Patelli, L., Prencipe, A. (2007). The Relationship between Voluntary Disclosure and Independent Directors in the Presence of a Dominant Shareholder. European Accounting Review, 16(1), 533.

Patten, D. (1992). Intra-industry environmental disclosures in response to the Alaskan oil spill: a note on legitimacy theory, Accounting, Organizations and Society, 17(5), 471-475.

Prencipe, A. (2004). Proprietary Costs and Determinants of Voluntary Segment Disclosure: Evidence from Italian Listed Companies. European Accounting Review, 13(2), 319-340.

Raffournier, B. (1995). The determinants of voluntary financial disclosure by Swiss listed companies. European Accounting Review, 4(2), 261-280.

RiskMetrics (2009). Study on Monitoring and Enforcement Practices in Corporate Governance in the Member States. Brussels: RiskMetrics.

Robb, S., Single, L., Zarzeski, M. (2001). Non-financial disclosures across Anglo-American countries, Journal of International Accounting, 10(1), 71-83. 
Robinson, J. Xue, Y., Yong, Y. (2011). Determinants of Disclosure Noncompliance and the Effect of the SEC Review: Evidence from the 2006 Mandated Remuneration Disclosure Regulations. The Accounting Review, 86(4), 1415-1444.

Schiehll E., Soares Terra P., Gomes Victor F. (2013), Determinants of voluntary executive stock option disclosure in Brazil, Journal of Management and Governance, 17(2), 331-361.

Suchman M. (1995), Managing Legitimacy: Strategic and Institutional Approaches, The Academy of Management Review, 20(3), 571-610.

Teixeira Lopes, P., Lima Rodrigues, L. (2007). Accounting for financial instruments: An analysis of the determinants of disclosure in the Portuguese stock exchange, The International Journal of Accounting, 42(1), 25-56.

Tilt, C. (1994). The influence of external pressure groups on corporate social disclosure: some empirical evidence, Accounting, Auditing \& Accountability Journal, 7(4), 47-72.

Verrecchia R. (2001), Essays on disclosure, Journal of Accounting and Economics, 32, 97-180.

Wade, J., Porac, J., Pollock, T. (1997). Worth, Words, and the Justification of Executive Pay. Journal of Organizational Behavior, 18(1), 641-664.

Wallace, R., Naser, K. (1995). Firm-specific determinants of the comprehensiveness of mandatory disclosure in the corporate annual reports of firms listed on the Stock Exchange of Hong Kong, Journal of Accounting and Public Policy, 14(4), 311-368.

Weimer, J., Pape, J. (1999). A Taxonomy of Systems of Corporate Governance. Corporate Governance: An International Review, 7(2), 152-166.

Wilmshurst, T., Frost G. (2000). Corporate environmental reporting. A test of legitimacy theory, Accounting Auditing \& Accountability Journal, 13(1), 10-26.

Wiseman R., Cuevas-Rodríguez G., Gomez-Mejia L., (2012), Towards a Social Theory of Agency, Journal of Management Studies, 49(1), 202-222. 
Table 1 - Main characteristics of the sample (Sample size $=234$ firms).

\begin{tabular}{|c|c|c|c|c|c|c|c|c|c|c|c|}
\hline & \multicolumn{3}{|c|}{ MEAN } & \multicolumn{2}{|c|}{ MEDIAN } & \multicolumn{2}{|c|}{ MIN } & \multicolumn{2}{|c|}{ MAX } & \multicolumn{2}{|c|}{ STAND. DEV } \\
\hline & ITA & UK & & ITA & UK & ITA & UK & ITA & $\mathrm{UK}$ & ITA & UK \\
\hline Ownership diffusion (\%) & 45.40 & 79.69 & **** & 43.67 & 85.21 & 11.51 & 15.41 & 88.92 & 99.21 & 16.49 & 15.61 \\
\hline Outside shareholders' attendance (\%) & 10.95 & 35.35 & **** & 6.81 & 40.62 & 0.00 & 0.00 & 70.32 & 84.96 & 12.41 & 30.78 \\
\hline Media coverage & 0.97 & 0.28 & & 0.00 & 0.00 & 0.00 & 0.00 & 26.00 & 14.00 & 3.21 & 1.74 \\
\hline CEO remuneration ( $€$ thousand) & $1,043.76$ & 885.01 & & 467.78 & 661.70 & 30.00 & 82.62 & 8.265 .00 & $3,827.54$ & $1,347.05$ & $7,615.87$ \\
\hline CEO remuneration change (\%) & -0.92 & 11.93 & * & -0.19 & 3.77 & -94.36 & -73.74 & 221.43 & 210.76 & 46.32 & 49.51 \\
\hline Market performance $(\%)$ & -49.15 & -43.00 & $\dagger$ & -51.65 & -44.55 & -97.40 & -96.38 & 42.74 & 62.50 & 23.74 & 29.78 \\
\hline Dissenting votes & 0.38 & 0.68 & $* * *$ & & & & & & & & \\
\hline Firm size ( $€$ million $)$ & $1,184.25$ & $1,819.30$ & & 101.18 & 108.43 & 2.93 & 2.17 & $60,639.05$ & $141,362.20$ & $6,186.61$ & $13,163.49$ \\
\hline Profitability & 0.03 & -0.04 & $*$ & 0.04 & 0.05 & -0.37 & -2.10 & 0.27 & 0.38 & 0.09 & 0.31 \\
\hline Financial leverage $(\%)$ & 64.03 & 58.90 & & 66.02 & 60.75 & 9.98 & 2.55 & 104.30 & 185.20 & 18.48 & 28.45 \\
\hline Remuneration complexity & 0.71 & 0.83 & $* * *$ & 0.78 & 0.90 & 0.37 & 0.29 & 0.93 & 0.95 & 0.17 & 0.13 \\
\hline $\begin{array}{l}\text { Industries (\%) } \\
\text { - Agriculture, forestry and fishing }\end{array}$ & 2.56 & 2.56 & & & & & & & & & \\
\hline - Mining & 0.85 & 0.85 & & & & & & & & & \\
\hline - Light manufacturing & 14.53 & 14.53 & & & & & & & & & \\
\hline - Heavy manufacturing & 35.90 & 35.90 & & & & & & & & & \\
\hline - Utilities & 10.27 & 10.27 & & & & & & & & & \\
\hline - Trade & 5.98 & 5.98 & & & & & & & & & \\
\hline - Real Estate & 9.40 & 9.40 & & & & & & & & & \\
\hline - Services & 20.51 & 20.51 & & & & & & & & & \\
\hline AIM & 0.00 & 0.36 & **** & & & & & & & & \\
\hline
\end{tabular}

Levels of significance: *** p $<0.01 ; * *$ p. $<0.05 ; * \mathrm{p}<0.10$.

Variables are defined as follows:

Ownership diffusion - the percentage of capital not owned by substantial shareholders (i.e. shareholders who own more than $3 \%$ of the voting capital), calculated at the start of the financial year; Outside shareholders' attendance - the percentage of voting shares owned by the outside shareholders (i.e. shareholders who are not either controlling shareholders or directors of the firm) that voted for the remuneration resolution at the previous annual general meeting; Media coverage - number of articles related to a firm's directors' remuneration published in the main national newspapers during the previous year; CEO remuneration - total amount of remuneration the CEO received in the previous financial year; CEO remuneration change - the percentage variation of the remuneration the CEO received in the year analysed compared with that received in the previous financial year; Market performance - the percentage variation of the share value at the start of the financial year compared with the share value at the start of the previous financial year; Dissenting votes - dichotomous variable that equals 1 if there was at least one outside shareholder who either abstained or voted against on the remuneration resolution at the previous annual general meeting, and 0 otherwise; Firm size - market capitalization of the firm at the start of the financial year; Profitability - ROA at the end of the previous financial year; Financial leverage - percentage ratio of the value of total debts to total assets at the start of the financial year; Remuneration complexity - total number of items applicable to the firm analysed divided by the total number of items in the index; Financial analysts' coverage - total number of financial analysts that published at least one report, during the previous financial year, on the firm analysed; Industry - set of dichotomous variables equal to 1 if the firm was classified into the $i$ one-digit SIC code; AIM - dichotomous variable that equals 1 if the firm was listed on the AIM and 0 otherwise. 
Table 2 - Average level of disclosure of specific items and overall disclosure

\begin{tabular}{|c|c|c|c|c|c|c|c|c|}
\hline & \multicolumn{3}{|c|}{ Type of disclosure } & \multicolumn{2}{|c|}{$\begin{array}{c}\text { FTSE } \\
\text { Match-paired }\end{array}$} & \multicolumn{2}{|c|}{$\begin{array}{c}\text { AIM } \\
\text { Match-paired }\end{array}$} \\
\hline & & Ita & UK FTSE & AIM & Ita & UK & Ita & UK \\
\hline & LOSURE OF SPECIFIC ITEMS & & & & & & & \\
\hline & REMUNERATION POLICY & & & & & & & \\
\hline & Directors' remuneration policy & M & M & $\mathrm{V}$ & 0.95 & 1.00 & 0.91 & 0.93 \\
\hline & Information on the Pay-performance link & M & M & $\mathrm{V}$ & 0.95 & 0.99 & 0.88 & 0.91 \\
\hline & Relative importance of fixed and variable components & $\mathrm{v}$ & M & $\mathrm{V}$ & 0.33 & 0.85 & 0.43 & 0.07 \\
\hline & Peer groups considered & $\mathrm{v}$ & $\mathrm{v}$ & $\mathrm{V}$ & 0.00 & 0.19 & 0.00 & 0.02 \\
\hline B & DESIGN OF SALARY AND FEES & & & & & & & \\
\hline & Criteria for setting-up of salaries & $\mathrm{V}$ & $\mathrm{V}$ & $\mathrm{V}$ & 0.01 & 0.85 & 0.00 & 0.38 \\
\hline & Fees payable to directors for being director, committee member, chair or SID & $\mathrm{V}$ & $\mathrm{V}$ & $\mathrm{V}$ & 0.29 & 0.43 & 0.19 & 0.04 \\
\hline C. & DESIGN OF BONUS SCHEMES & & & & & & & \\
\hline & Adopted (Yes/No) & $\mathrm{V}$ & $\mathrm{V}$ & $\mathrm{V}$ & 0.74 & 0.95 & 0.64 & 0.62 \\
\hline & How the scheme contributes to the firm's long term interest & $\mathrm{V}$ & $\mathrm{V}$ & $\mathrm{V}$ & 0.00 & 0.01 & 0.00 & 0.00 \\
\hline & Performance criteria adopted & $\mathrm{V}$ & $\mathrm{v}$ & $\mathrm{V}$ & 0.43 & 0.87 & 0.34 & 0.39 \\
\hline & Performance measure(s) adopted & $\mathrm{V}$ & $\mathrm{v}$ & $\mathrm{v}$ & 0.14 & 0.53 & 0.28 & 0.13 \\
\hline & Weight of each performance measure adopted & $\mathrm{v}$ & $\mathrm{v}$ & $\mathrm{v}$ & 0.04 & 0.39 & 0.20 & 0.10 \\
\hline & Performance target for each performance measure adopted & $\mathrm{V}$ & $\mathrm{v}$ & $\mathrm{V}$ & 0.03 & 0.09 & 0.06 & 0.05 \\
\hline & Amount earned for each target level of each performance measure adopted & $\mathrm{V}$ & $\mathrm{V}$ & $\mathrm{V}$ & 0.03 & 0.07 & 0.09 & 0.04 \\
\hline & Aim of the bonus & $\mathrm{V}$ & $\mathrm{v}$ & $\mathrm{V}$ & 0.17 & 0.53 & 0.00 & 0.13 \\
\hline & Rationale for the performance criteria & $\mathrm{v}$ & $\mathrm{v}$ & $\mathrm{V}$ & 0.02 & 0.14 & 0.00 & 0.03 \\
\hline & Sufficient information on deferment periods & $\mathrm{V}$ & $\mathrm{v}$ & $\mathrm{V}$ & 0.18 & 0.89 & 0.16 & 0.49 \\
\hline & SHARE-BASED PAYMENTS (SBP) & & & & & & & \\
\hline & GRANTED DURING THE YEAR: & & & & & & & \\
\hline & Number of SBPs & M & M & $\mathrm{V}$ & 0.99 & 0.99 & 1.00 & 0.91 \\
\hline & Exercise price & M & M & $\mathrm{V}$ & 0.90 & 1.00 & 1.00 & 0.83 \\
\hline & Vesting period & M & M & $\mathrm{V}$ & 0.85 & 0.91 & 0.67 & 0.67 \\
\hline & Exercise period & M & M & $\mathrm{v}$ & 0.88 & 1.00 & 0.67 & 0.64 \\
\hline & Beneficiaries & M & M & $\mathrm{V}$ & 0.90 & 1.00 & 1.00 & 0.85 \\
\hline & Market price & M & M & $\mathrm{V}$ & 0.70 & 0.83 & 0.83 & 0.58 \\
\hline & Performance-conditioned vesting & M & M & $\mathrm{V}$ & 0.80 & 0.97 & 1.00 & 0.52 \\
\hline & How the performance criteria contributes to the firm's long term interest & $\mathrm{V}$ & $\mathrm{V}$ & $\mathrm{V}$ & 0.00 & 0.01 & 0.00 & 0.00 \\
\hline & Information on the performance-conditioned vesting & M & M & $\mathrm{V}$ & 0.78 & 0.97 & 1.00 & 0.44 \\
\hline & Performance measure(s) adopted & M & M & $\mathrm{V}$ & 0.67 & 0.97 & 1.00 & 0.42 \\
\hline & Weight of each performance measure adopted & M & M & $\mathrm{V}$ & 0.44 & 0.93 & 0.75 & 0.42 \\
\hline & Target level for each performance $\mathrm{m}$ & M & M & $\mathrm{V}$ & 0.00 & 0.93 & 0.00 & 0.40 \\
\hline & Amount earned for each target level of each performance measure adopted & M & M & $\mathrm{V}$ & 0.33 & 0.92 & 0.25 & 0.40 \\
\hline & Rationale for the performance criteria & $\mathrm{V}$ & $\mathrm{V}$ & $\mathrm{V}$ & 0.11 & 0.33 & 0.25 & 0.06 \\
\hline & Policy regarding shares' retention & M & M & $\mathrm{v}$ & 0.56 & 0.45 & 1.00 & 0.06 \\
\hline & Aim of the SBP & M & M & $\mathrm{V}$ & 0.90 & 0.72 & 1.00 & 0.44 \\
\hline & EXERCISED DURING THE YEAR: & & & & & & & \\
\hline & Number of SBPs & M & M & $\mathrm{V}$ & 0.96 & 1.00 & 0.98 & 0.88 \\
\hline & For each SBP exercised the number of shares involved & M & M & $\mathrm{V}$ & 0.63 & 1.00 & 0.67 & 0.33 \\
\hline & Exercise price & M & M & $\mathrm{V}$ & 0.63 & 1.00 & 0.50 & 0.33 \\
\hline & UNEXERCISED AT THE END OF THE YEAR: & & & & & & & \\
\hline & Number of SBPs & M & M & $\mathrm{V}$ & 0.96 & 0.99 & 0.95 & 0.83 \\
\hline & Exercise price & M & M & $\mathrm{V}$ & 0.92 & 0.99 & 0.81 & 0.84 \\
\hline & Vestin & M & M & $\mathrm{V}$ & 0.77 & 0.86 & 0.73 & 0.62 \\
\hline & Exercise period & M & M & $\mathrm{V}$ & 0.81 & 0.97 & 0.73 & 0.67 \\
\hline & Beneficiaries & M & M & $\mathrm{V}$ & 0.88 & 0.99 & 0.85 & 0.81 \\
\hline & Performance-conditioned vesting & M & M & $\mathrm{V}$ & 0.72 & 0.94 & 0.62 & 0.55 \\
\hline & How the performance criteria contributes to the firm's long term interest & $\mathrm{V}$ & $\mathrm{V}$ & $\mathrm{V}$ & 0.00 & 0.01 & 0.00 & 0.00 \\
\hline & rformance-conditioned vesting & M & M & $\mathrm{V}$ & 0.64 & 0.89 & 0.50 & 0.27 \\
\hline & e(s) adopted & M & M & $\mathrm{V}$ & 0.52 & 0.86 & 0.46 & 0.26 \\
\hline & Weight of each pe & M & M & $\mathrm{V}$ & 0.32 & 0.85 & 0.46 & 0.26 \\
\hline & Target level for each performance measure adopted & M & M & $\mathrm{v}$ & 0.14 & 0.76 & 0.33 & 0.26 \\
\hline & rned for each target level of each performance measure adopted & M & M & $\mathrm{v}$ & 0.27 & 0.74 & 0.33 & 0.26 \\
\hline & Rationale for the performance criteria & $\mathrm{V}$ & $\mathrm{V}$ & $\mathrm{V}$ & 0.09 & 0.27 & 0.00 & 0.05 \\
\hline & Policy regarding shares' retention & M & M & $\mathrm{V}$ & 0.56 & 0.41 & 0.58 & 0.04 \\
\hline & Aim of the SBP & $\mathrm{M}$ & $\mathrm{M}$ & $\mathrm{V}$ & 0.92 & 0.65 & 0.77 & 0.27 \\
\hline E. & PENSION SCHEMES & & & & & & & \\
\hline & Type: $\mathrm{d}$ & $\mathrm{V}$ & M & $\mathrm{V}$ & 0.00 & 1.00 & 0.00 & 0.79 \\
\hline & Changes in the accrued benefits during the yc & $\mathrm{V}$ & M & $\mathrm{V}$ & 0.00 & 1.00 & 0.00 & 0.67 \\
\hline F. & EXECUTIVES' CONTRACT AND TERMINATION PAYMENTS & & & & & & & \\
\hline & Duration of contracts & M & M & $\mathrm{V}$ & 1.00 & 0.69 & 0.98 & 0.30 \\
\hline & Applicable notice period & $\mathrm{v}$ & M & $\mathrm{V}$ & 0.00 & 0.97 & 0.00 & 0.63 \\
\hline & Details of provisions for termination payments & $\mathrm{M}$ & M & $\mathrm{v}$ & 0.86 & 0.71 & 0.76 & 0.18 \\
\hline & REMUNERATION PAID TO EACH DIRECTOR & & & & & & & \\
\hline & Total remuneration & M & & & 1.00 & 1.00 & 1.00 & 0.83 \\
\hline & Salary & M & M & $\mathrm{V}$ & 1.00 & 0.99 & 0.98 & 0.77 \\
\hline & Profit sharing and/or bonus payments & M & M & $\mathrm{V}$ & 0.89 & 0.97 & 0.83 & 0.58 \\
\hline & Termination payment to each executive who left the firm during the year & M & M & $\mathrm{V}$ & 1.00 & 0.73 & 0.67 & 0.63 \\
\hline & Estimated value of benefits in-kind & M & M & $\mathrm{V}$ & 0.81 & 0.96 & 0.71 & 0.58 \\
\hline & Type of benefits in-kind & $\mathrm{V}$ & $\mathrm{V}$ & $\mathrm{V}$ & 0.13 & 0.48 & 0.06 & 0.26 \\
\hline & Amount earned by exercising SBPs during the year & $\mathrm{V}$ & $\mathrm{V}$ & $\mathrm{V}$ & 0.94 & 0.95 & 0.98 & 0.89 \\
\hline & No of SBPs granted during the year & M & M & $\mathrm{V}$ & 0.97 & 0.99 & 1.00 & 0.86 \\
\hline & No of SBPs exercised dur & M & M & $\mathrm{V}$ & 0.95 & 1.00 & 0.98 & 0.88 \\
\hline & No of SBPs unexercised at the end of the year & M & M & $\mathrm{V}$ & 0.95 & 1.00 & 0.95 & 0.86 \\
\hline & Details of "Other remuneration" & $\mathrm{V}$ & $\mathrm{V}$ & $\mathrm{V}$ & 0.58 & 0.67 & 0.57 & 0.17 \\
\hline & REMUNERATION SECTION IN THE ANNUAL REPORT (Yes/No) & $\mathrm{V}$ & M & $\mathrm{V}$ & 0.64 & 0.87 & 0.62 & 0.66 \\
\hline & AL DISCLOSURE INDEX (TDI) & & & & 0.56 & 0.75 & 0.55 & 0.47 \\
\hline & bs $($ Sample size $=234$ firms $)$ & & & & 75 & 75 & 42 & 42 \\
\hline
\end{tabular}

Legend: $\mathrm{M}=$ Mandatory information; $\mathrm{V}=$ Voluntary information. 
Table 3 -Voluntary disclosure index (VDI): descriptive results

\begin{tabular}{|c|c|c|c|c|c|c|c|c|c|c|c|c|c|}
\hline & \multirow{2}{*}{$\begin{array}{l}\text { No } \\
\text { Obs }\end{array}$} & \multicolumn{2}{|c|}{ Mean } & \multicolumn{4}{|c|}{ Median } & \multicolumn{2}{|c|}{ Min } & \multicolumn{2}{|c|}{ Max } & \multicolumn{2}{|c|}{ Stand. Dev } \\
\hline & & ITA & $\mathrm{UK}$ & & ITA & UK & & ITA & UK & ITA & UK & ITA & UK \\
\hline FULL SAMPLE & 234 & 0.246 & 0.466 & $* * *$ & 0.259 & 0.500 & $* * *$ & 0.020 & 0.059 & 0.500 & 0.904 & 0.127 & 0.161 \\
\hline FTSE MATCH-PAIR & 150 & 0.247 & 0.465 & $* * *$ & 0.259 & 0.500 & $* * *$ & 0.020 & 0.059 & 0.500 & 0.710 & 0.123 & 0.135 \\
\hline AIM MATCH-PAIR & 84 & 0.243 & 0.466 & $* * *$ & 0.250 & 0.474 & $* * *$ & 0.042 & 0.076 & 0.500 & 0.904 & 0.134 & 0.202 \\
\hline
\end{tabular}

Levels of significance: $* * *$ p. $<0.01$.

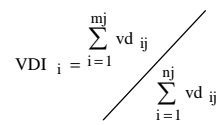

Where:

$\mathrm{VDI}_{\mathrm{i}}$ is the voluntary disclosure index of the firm $i$;

$\mathrm{vd}_{\mathrm{ij}}$ is the value for a voluntary disclosure index item $j$, for firm $i$.

$m_{j}$ is the number of voluntary disclosure items which are relevant to firm $i$ and were actually disclosed, and $n_{j}$ is the maximum number of voluntary disclosure items that can be disclosed by firm $i$ given the elements that are comprised in the directors' remuneration package. 
Table 4 - Pearson correlation Matrix between the Voluntary disclosure index and the independent and control variables

\begin{tabular}{|c|c|c|c|c|c|c|c|c|c|c|c|c|c|c|c|c|c|c|c|c|c|}
\hline \multicolumn{22}{|c|}{ Panel A - Full sample $($ n. obs $=230)$} \\
\hline & 1 & 2 & 3 & 4 & 5 & 6 & 7 & 8 & 9 & 10 & 11 & 12 & 13 & 14 & 15 & 16 & 17 & 18 & 19 & 20 & 21 \\
\hline 1. Voluntary disclosure index $\left({ }^{\mathrm{a}}\right)$ & 1 & & & & & & & & & & & & & & & & & & & & \\
\hline 2. Country $(\mathrm{UK}=1 ; \mathrm{ITA}=0)$ & 0.54 & 1 & & & & & & & & & & & & & & & & & & & \\
\hline 3. Ownership diffusion & 0.44 & 0.73 & 1 & & & & & & & & & & & & & & & & & & \\
\hline 4. Outside shareholders' attendance & 0.35 & 0.46 & 0.56 & 1 & & & & & & & & & & & & & & & & & \\
\hline 5. Media coverage $\left({ }^{\mathrm{a}}\right)$ & 0.05 & -0.06 & 0.06 & 0.07 & 1 & & & & & & & & & & & & & & & & \\
\hline 6. CEO remuneration $\left({ }^{\mathrm{a}}\right)$ & 0.02 & 0.04 & 0.01 & 0.05 & 0.17 & 1 & & & & & & & & & & & & & & & \\
\hline 7. CEO remuneration change & 0.04 & 0.13 & 0.12 & 0.08 & 0.00 & -0.25 & 1 & & & & & & & & & & & & & & \\
\hline 8. Market performance & -0.03 & 0.11 & 0.01 & 0.11 & 0.04 & -0.05 & 0.00 & 1 & & & & & & & & & & & & & \\
\hline 9. Dissenting votes & 0.29 & 0.30 & 0.37 & 0.60 & 0.21 & 0.14 & 0.07 & 0.07 & 1 & & & & & & & & & & & & \\
\hline 10. Firm size $\left({ }^{\mathrm{a}}\right)$ & 0.04 & 0.01 & 0.12 & 0.42 & 0.53 & 0.25 & -0.02 & 0.25 & 0.50 & 1 & & & & & & & & & & & \\
\hline 11. Profitability & -0.09 & -0.15 & -0.07 & 0.15 & -0.02 & -0.06 & 0.01 & 0.18 & 0.22 & 0.28 & 1 & & & & & & & & & & \\
\hline 12. Financial leverage & -0.05 & -0.11 & 0.02 & 0.20 & 0.15 & 0.08 & 0.12 & -0.10 & 0.24 & 0.18 & 0.15 & 1 & & & & & & & & & \\
\hline 13. Remuneration complexity & -0.08 & 0.38 & 0.44 & 0.41 & 0.17 & 0.15 & 0.11 & 0.09 & 0.37 & 0.33 & 0.08 & 0.16 & 1 & & & & & & & & \\
\hline $\begin{array}{l}\text { 14. Agriculture, forestry and fishing }\end{array}$ & $\begin{aligned}-0.00 \\
0.03\end{aligned}$ & 0.00 & $\begin{array}{r}0.08 \\
-0.08\end{array}$ & $\begin{array}{r}.0 .41 \\
-0.04\end{array}$ & $\begin{array}{l}0.02 \\
-0.02\end{array}$ & $\begin{array}{l}0.010 \\
-0.03\end{array}$ & -0.03 & 0.05 & 0.00 & 0.02 & 0.01 & $\begin{array}{c}.0 .10 \\
-0.07\end{array}$ & -0.25 & 1 & & & & & & & \\
\hline $\begin{array}{l}\text { 15. Mining } \\
\text { S }\end{array}$ & 0.03 & 0.00 & -0.01 & -0.03 & -0.04 & -0.01 & -0.09 & -0.03 & 0.05 & 0.05 & 0.02 & 0.05 & 0.01 & -0.02 & 1 & & & & & & \\
\hline 16. Light manufacturing & 0.05 & 0.00 & 0.04 & 0.07 & 0.07 & 0.03 & 0.07 & 0.08 & 0.05 & 0.09 & $\begin{array}{r}.0 .02 \\
-0.12\end{array}$ & 0.11 & 0.00 & $\begin{array}{l}-0.02 \\
-0.04\end{array}$ & -0.07 & 1 & & & & & \\
\hline 17. Heavy manufacturing & -0.03 & 0.00 & -0.02 & -0.03 & -0.05 & -0.06 & 0.00 & 0.03 & -0.07 & -0.04 & -0.01 & -0.26 & 0.06 & -0.07 & -0.12 & -0.31 & 1 & & & & \\
\hline 18. Utilities & 0.07 & 0.00 & $\begin{array}{r}-0.02 \\
0.03\end{array}$ & 0.10 & 0.29 & $\begin{array}{r}-0.00 \\
0.04\end{array}$ & 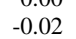 & $\begin{array}{l}0.03 \\
-0.02\end{array}$ & $\begin{array}{r}-0.01 \\
0.12\end{array}$ & 0.23 & $\begin{array}{r}-0.01 \\
0.02\end{array}$ & $\begin{array}{r}-0.20 \\
0.12\end{array}$ & 0.04 & $\begin{array}{l}-0.03 \\
-0.03\end{array}-100$ & -0.05 & $\begin{array}{l}-0.01 \\
-0.14\end{array}$ & -0.25 & 1 & & & \\
\hline 19. Trade & 0.02 & 0.00 & 0.09 & 0.05 & -0.06 & 0.05 & -0.07 & 0.00 & 0.06 & 0.03 & 0.05 & 0.06 & 0.04 & -0.02 & -0.04 & -0.10 & -0.19 & -0.09 & 1 & & \\
\hline 20. Real Estate & 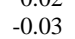 & 0.00 & $\begin{array}{r}-0.04 \\
-0.04\end{array}-10$ & 0.02 & 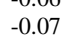 & 0.00 & 0.03 & $\begin{array}{l}0.00 \\
-0.07\end{array}$ & 0.00 & $\begin{array}{l}.0 .03 \\
-0.02\end{array}$ & 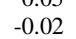 & 0.03 & $\begin{array}{c}-0.12 \\
-0.12\end{array}$ & $\begin{array}{l}-0.02 \\
-0.03\end{array}-100$ & $\begin{array}{l}-0.05 \\
-0.05\end{array}$ & $\begin{array}{l}-0.13 \\
-0.13\end{array}-10$ & $\begin{array}{l}-0.24 \\
-0.24\end{array}-19$ & $\begin{array}{l}-0.03 \\
-0.11\end{array}$ & -0.08 & 1 & \\
\hline 21. Services & -0.06 & 0.00 & -0.03 & -0.12 & -0.11 & 0.00 & 0.02 & -0.04 & -0.11 & -0.24 & 0.08 & 0.06 & 0.02 & -0.05 & -0.08 & -0.21 & -0.38 & -0.17 & -0.13 & -0.16 & 1 \\
\hline \multicolumn{22}{|c|}{ Panel B - Italian sample (n. obs = 116) } \\
\hline & 1 & 2 & 3 & 4 & 5 & 6 & 7 & 8 & 9 & 10 & 11 & 12 & 13 & 14 & 15 & 16 & 17 & 18 & 19 & 20 & 21 \\
\hline 1. Voluntary disclosure index $\left({ }^{\mathrm{a}}\right)$ & 1 & & & & & & & & & & & & & & & & & & & & \\
\hline 2. Country $(\mathrm{UK}=1 ; \mathrm{ITA}=0)$ & & . & & & & & & & & & & & & & & & & & & & \\
\hline 3. Ownership diffusion & -0.12 & . & 1 & & & & & & & & & & & & & & & & & & \\
\hline 4. Outside shareholders' attendance & 0.12 & . & 0.39 & 1 & & & & & & & & & & & & & & & & & \\
\hline 5. Media coverage $\left({ }^{\mathrm{a}}\right)$ & 0.11 & . & 0.23 & 0.19 & 1 & & & & & & & & & & & & & & & & \\
\hline 6. CEO remuneration $\left({ }^{\mathrm{a}}\right)$ & 0.05 & & -0.06 & 0.08 & 0.26 & 1 & & & & & & & & & & & & & & & \\
\hline 7. CEO remuneration change & 0.01 & . & $\begin{array}{l}-0.00 \\
0.08\end{array}$ & 0.16 & $\begin{array}{l}0.20 \\
0.05\end{array}$ & -0.36 & 1 & & & & & & & & & & & & & & \\
\hline 8. Market performance & 0.05 & . & -0.13 & 0.00 & 0.03 & -0.18 & 0.03 & 1 & & & & & & & & & & & & & \\
\hline 9. Dissenting votes & 0.09 & . & 0.13 & 0.17 & 0.32 & 0.29 & -0.03 & -0.01 & 1 & & & & & & & & & & & & \\
\hline 10. Firm size $\left({ }^{\mathrm{a}}\right)$ & -0.02 & . & 0.06 & 0.11 & 0.61 & 0.38 & -0.06 & 0.23 & 0.49 & 1 & & & & & & & & & & & \\
\hline 11. Profitability & -0.16 & & -0.07 & -0.22 & 0.13 & 0.00 & -0.02 & 0.30 & 0.17 & 0.47 & 1 & & & & & & & & & & \\
\hline 12. Financial leverage & -0.03 & . & 0.22 & 0.14 & 0.14 & 0.17 & -0.10 & -0.18 & 0.19 & -0.05 & -0.13 & 1 & & & & & & & & & \\
\hline 13. Remuneration complexity & -0.60 & . & 0.17 & -0.05 & 0.24 & 0.23 & 0.06 & 0.00 & 0.14 & 0.31 & 0.32 & 0.20 & 1 & & & & & & & & \\
\hline $\begin{array}{l}\text { 14. Agriculture, forestry and fishing } \\
\text { (a) }\end{array}$ & $\begin{array}{r}-0.00 \\
0.08\end{array}$ & : & -0.04 & $\begin{array}{l}-0.05 \\
-0.04\end{array}$ & $\begin{array}{r}0.24 \\
-0.02\end{array}$ & $\begin{array}{r}0.09 \\
-0.09\end{array}$ & 0.00 & 0.12 & $\begin{array}{r}0.07 \\
-0.07\end{array}$ & $\begin{array}{l}0.01 \\
0.01\end{array}$ & $\begin{array}{l}0.02 \\
0.00\end{array}$ & $\begin{array}{c}0.20 \\
-0.19\end{array}$ & -0.18 & 1 & & & & & & & \\
\hline $\begin{array}{l}\text { 15. Mining } \\
\text {, }\end{array}$ & 0.05 & . & -0.01 & -0.07 & -0.04 & 0.02 & -0.10 & -0.05 & 0.10 & 0.06 & 0.02 & -0.09 & $\begin{array}{l}-0.04 \\
-0.04\end{array}$ & -0.02 & 1 & & & & & & \\
\hline 16. Light manufacturing & 0.06 & . & -0.02 & -0.06 & 0.07 & 0.02 & 0.11 & 0.02 & 0.03 & 0.07 & -0.03 & 0.07 & -0.02 & -0.04 & -0.07 & 1 & & & & & \\
\hline 17. Heavy manufacturing & -0.06 & . & -0.09 & -0.22 & -0.01 & -0.04 & -0.06 & 0.14 & -0.14 & -0.03 & 0.15 & -0.20 & 0.03 & -0.07 & -0.12 & -0.31 & 1 & & & & \\
\hline 18. Utilities & $\begin{aligned}-0.00 \\
0.08\end{aligned}$ & . & 0.05 & $\begin{array}{c}-0.26 \\
0.26\end{array}$ & $\begin{array}{l}-0.01 \\
0.26\end{array}$ & $\begin{aligned}-0.04 \\
0.07\end{aligned}$ & -0.03 & $\begin{array}{r}0.05 \\
-0.05\end{array}$ & 0.20 & 0.23 & 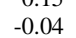 & $\begin{array}{r}-0.20 \\
0.05\end{array}$ & 0.01 & $\begin{array}{l}-0.01 \\
-0.03\end{array}$ & $\begin{array}{l}-0.05 \\
-0.05\end{array}$ & $\begin{array}{l}-0.01 \\
-0.14\end{array}$ & -0.25 & 1 & & & \\
\hline 19. Trade & -0.06 & . & 0.20 & 0.08 & -0.06 & 0.06 & -0.08 & -0.01 & 0.10 & 0.04 & 0.07 & 0.07 & 0.04 & -0.02 & -0.04 & -0.10 & -0.19 & -0.09 & 1 & & \\
\hline 20. Real Estate & -0.02 & . & 0.03 & 0.15 & $\begin{array}{l}-0.00 \\
-0.08\end{array}$ & $\begin{array}{r}-0.04 \\
-0.04\end{array}$ & -0.02 & -0.12 & 0.05 & -0.03 & -0.10 & 0.08 & $\begin{array}{r}.0 .04 \\
-0.06\end{array}$ & -0.03 & -0.05 & -0.13 & -0.24 & -0.11 & -0.08 & 1 & \\
\hline 21. Services & -0.04 & & -0.04 & -0.01 & -0.13 & -0.02 & 0.10 & -0.07 & -0.13 & -0.22 & -0.10 & 0.12 & 0.05 & -0.05 & -0.08 & -0.21 & -0.38 & -0.17 & -0.13 & -0.16 & 1 \\
\hline
\end{tabular}




\begin{tabular}{|c|c|c|c|c|c|c|c|c|c|c|c|c|c|c|c|c|c|c|c|c|c|}
\hline \multicolumn{22}{|c|}{ Panel C - UK sample $($ No obs $=114)$} \\
\hline & 1 & 2 & 3 & 4 & 5 & 6 & 7 & 8 & 9 & 10 & 11 & 12 & 13 & 14 & 15 & 16 & 17 & 18 & 19 & 20 & $21 \quad 22$ \\
\hline 1. Voluntary disclosure index $\left({ }^{\mathrm{a}}\right)$ & 1 & & & & & & & & & & & & & & & & & & & & \\
\hline 2. Country $(\mathrm{UK}=1 ;$ ITA $=0)$ & & & & & & & & & & & & & & & & & & & & & \\
\hline 3. Ownership diffusion & 0.32 & . & 1 & & & & & & & & & & & & & & & & & & \\
\hline 4. Outside shareholders' attendance & 0.18 & . & 0.40 & 1 & & & & & & & & & & & & & & & & & \\
\hline 6. CEO remuneration $\left({ }^{\mathrm{a}}\right)$ & -0.08 & & 0.01 & 0.02 & 0.04 & 1 & & & & & & & & & & & & & & & \\
\hline 7. CEO remuneration change & -0.10 & & 0.00 & -0.02 & -0.04 & -0.16 & 1 & & & & & & & & & & & & & & \\
\hline 8. Market performance & -0.28 & & -0.09 & 0.09 & 0.07 & 0.05 & -0.04 & 1 & & & & & & & & & & & & & \\
\hline 9. Dissenting votes & 0.25 & . & 0.34 & 0.79 & 0.13 & -0.05 & 0.10 & 0.07 & 1 & & & & & & & & & & & & \\
\hline 10. Firm size $\left({ }^{a}\right)$ & 0.12 & & 0.27 & 0.65 & 0.45 & 0.12 & 0.01 & 0.27 & 0.56 & 1 & & & & & & & & & & & \\
\hline 11. Profitability & 0.04 & . & 0.10 & 0.31 & -0.10 & -0.09 & 0.05 & 0.20 & 0.36 & 0.27 & 1 & & & & & & & & & & \\
\hline 12. Financial leverage & 0.04 & & 0.10 & 0.32 & 0.16 & 0.02 & 0.29 & -0.05 & 0.36 & 0.32 & 0.20 & 1 & & & & & & & & & \\
\hline 13. Remuneration complexity & 0.06 & & 0.39 & 0.54 & 0.15 & 0.00 & 0.06 & 0.10 & 0.51 & 0.42 & 0.12 & 0.26 & 1 & & & & & & & & \\
\hline 14. Agriculture, forestry and fishing & 0.00 & & -0.19 & -0.06 & -0.02 & 0.03 & -0.07 & 0.00 & 0.06 & 0.02 & 0.02 & 0.00 & -0.40 & 1 & & & & & & & \\
\hline 15. Mining & 0.01 & & -0.01 & -0.03 & -0.03 & -0.05 & -0.08 & -0.02 & 0.00 & 0.04 & 0.03 & 0.14 & 0.08 & -0.02 & 1 & & & & & & \\
\hline 16. Light manufacturing & 0.05 & & 0.13 & 0.14 & 0.07 & 0.05 & 0.03 & 0.14 & 0.08 & 0.10 & -0.17 & 0.14 & 0.04 & -0.04 & -0.07 & 1 & & & & & \\
\hline 17. Heavy manufacturing & -0.02 & & 0.04 & 0.04 & -0.11 & -0.09 & 0.06 & -0.06 & 0.01 & -0.04 & -0.06 & -0.30 & 0.13 & -0.07 & -0.12 & -0.31 & 1 & & & & \\
\hline 18. Utilities & 0.08 & & 0.02 & 0.06 & 0.34 & 0.01 & -0.02 & -0.01 & 0.05 & 0.23 & 0.04 & 0.17 & 0.08 & -0.03 & -0.05 & -0.14 & -0.25 & 1 & & & \\
\hline 19. Trade & 0.12 & $\cdot$ & 0.07 & 0.05 & -0.05 & 0.04 & -0.06 & 0.01 & 0.02 & 0.02 & 0.05 & 0.06 & 0.04 & -0.02 & -0.04 & -0.10 & -0.19 & -0.09 & 1 & & \\
\hline 20. Real Estate & -0.06 & . & -0.14 & -0.02 & -0.06 & 0.05 & 0.07 & -0.04 & -0.05 & 0.00 & 0.00 & 0.00 & -0.25 & -0.03 & -0.05 & -0.13 & -0.24 & -0.11 & -0.08 & 1 & \\
\hline 21. Services & -0.12 & & -0.07 & -0.20 & -0.10 & 0.02 & -0.06 & -0.02 & -0.10 & -0.25 & 0.15 & 0.02 & -0.03 & -0.05 & -0.08 & -0.21 & -0.38 & -0.17 & -0.13 & -0.16 & 1 \\
\hline 22. AIM segment & -0.06 & & -0.33 & -0.80 & -0.14 & -0.17 & -0.09 & -0.10 & -0.83 & -0.64 & -0.31 & -0.37 & -0.53 & -0.07 & -0.01 & -0.06 & -0.04 & -0.08 & -0.04 & -0.06 & 0.24 \\
\hline
\end{tabular}

The bold value indicates statistical significance at $\mathrm{p}<0.05$.

Note:

(a) Calculated using the natural logarithm avoid heteroskedasticity.

See table 1 for the definition of the variables.

One Italian firm and one UK firm were dropped because of the lack of data about CEO remuneration. Two UK firms were dropped because of the lack of data about outside shareholders' attendance and dissenting votes.

The control variable AIM has been included only in the correlation matrix for the UK sub-sample as in Italy the AIM has been established only in 2012. 
Table 5 - Regression results on voluntary disclosure index.

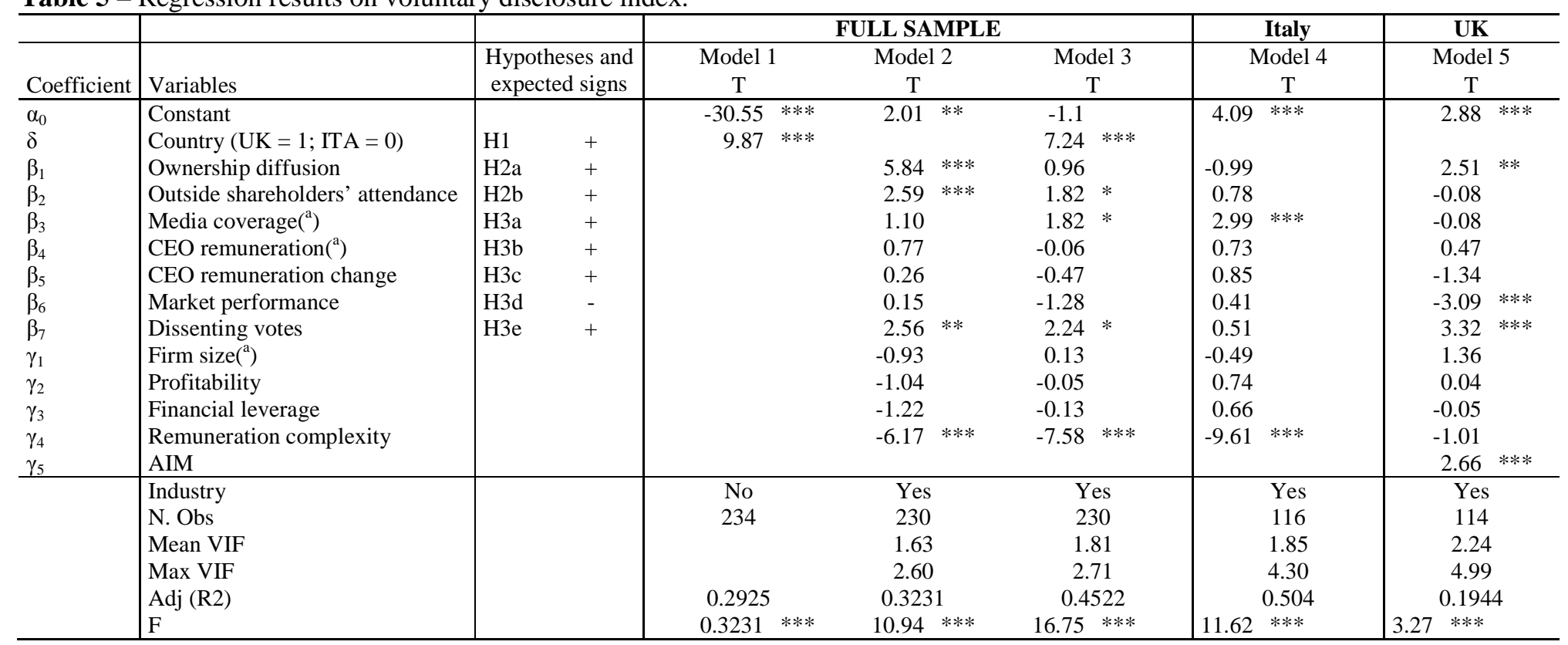

Levels of significance: $* * * \mathrm{p}<0.01 ; * * \mathrm{p} .<0.05 ; * \mathrm{p}<0.10$.

Note:

$\left({ }^{\mathrm{a}}\right)$ Calculated using the natural logarithm avoid heteroskedasticity.

$\alpha$ is the coefficient for constant;

$\beta$ is the coefficient for the independent explanatory variables;

$\gamma$ is the coefficient of the independent control variables;

$\delta$ is the coefficient for measuring the country effect.

See table 1 for the definition of the variables.

One Italian firm and one UK firm were dropped because of the lack of data about CEO remuneration. Two UK firms were dropped because of the lack of data about outside shareholders' attendance and dissenting votes.

The control variable AIM segment has been included only in the regression analysis for the UK sub-sample, as in Italy the AIM has been established only in 2012 . 